Rhode Island College

Digital Commons @ RIC

Master's Theses, Dissertations, Graduate

Master's Theses, Dissertations, Graduate Research and Major Papers Overview

Research and Major Papers

$11-24-2014$

\title{
TRFLP Analysis of the Effect of a Forest-to-Gap Ectone on Soil Microbial Diversity
}

Ronald Smith

Rhode Island College

Follow this and additional works at: https://digitalcommons.ric.edu/etd

Part of the Terrestrial and Aquatic Ecology Commons

\section{Recommended Citation}

Smith, Ronald, "TRFLP Analysis of the Effect of a Forest-to-Gap Ectone on Soil Microbial Diversity" (2014). Master's Theses, Dissertations, Graduate Research and Major Papers Overview. 107.

https://digitalcommons.ric.edu/etd/107

This Thesis is brought to you for free and open access by the Master's Theses, Dissertations, Graduate Research and Major Papers at Digital Commons @ RIC. It has been accepted for inclusion in Master's Theses, Dissertations, Graduate Research and Major Papers Overview by an authorized administrator of Digital Commons @ RIC. For more information, please contact digitalcommons@ric.edu. 
I

Approved:

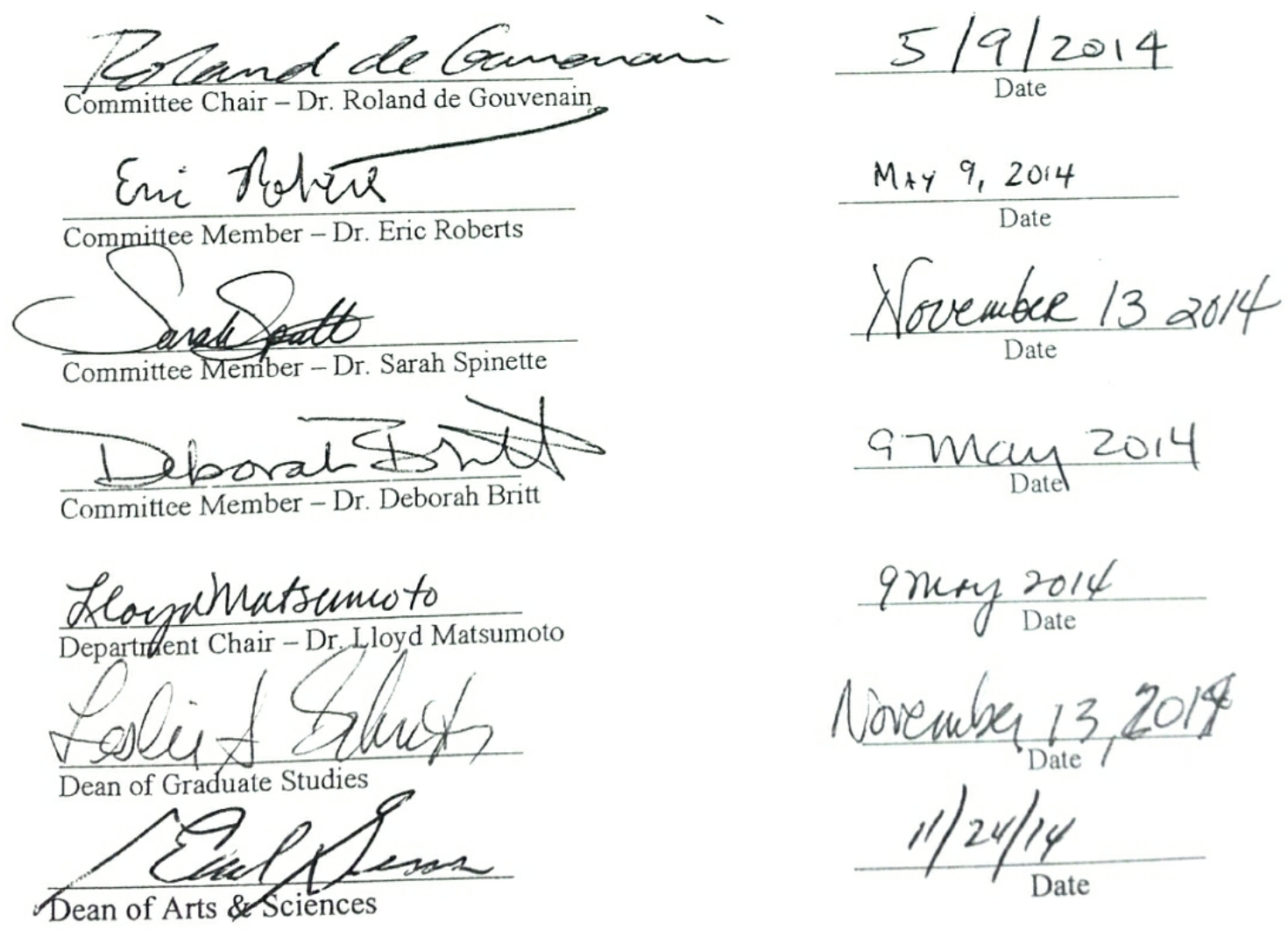




\title{
TRFLP ANALYSIS OF THE EFFECT OF A FOREST-TO-GAP ECTONE ON SOIL MICROBIAL DIVERSITY
}

\author{
By Ronald Smith
}

\begin{abstract}
A Thesis Submitted in Partial Fulfillment of the Requirements for the Master of Arts in the Department of Biology
\end{abstract}

The Faculty of Arts and Sciences

Rhode Island College

November $24^{\text {th }}, 2014$ 


\section{ABSTRACT}

To investigate how soil microbial diversity is influenced by the formation of an experimental edge-creating gap within a southern New England oak-hickory forest, I used a molecular fingerprinting technique known as terminal restriction fragment length polymorphism (TRFLP). Sequence variability in the $16 \mathrm{~S}$ ribosomal RNA (rRNA) gene in soil bacterial communities is detected by differences in the length and abundance of fragments produced by digesting PCR products amplified from rRNA genes. The different patterns observed are assumed to represent unique phylotypes.

How does the forest-gap ecotone influence soil bacterial diversity? Based on other studies, I hypothesized that the edge would contain the most diverse bacterial community, followed by the gap, and as distance from the gap into the forest increased, bacterial diversity would decrease.

Soil samples were collected along 40m transects perpendicular to the northern edge of the gap. DNA was extracted from each sample, PCR was used to amplify the $16 \mathrm{~S}$ rRNA gene, and DNA fragments were cut by restriction enzyme digestion and separated via electrophoresis. The DNA fragments were analyzed by TRFLP.

Environmental variables (soil $\mathrm{pH}$, soil temperature and soil gravimetric moisture) were different in the gap compared to all other distances, but not significantly so. Phylotype richness and diversity (Simpson's index) was greatest at the edge. Canonical Correspondence Analysis (CCA) produced a phylotype-by-distance ordination that supports my hypothesis and shows that the edge is an ecotone (transitional zone) between the gap and forest. 


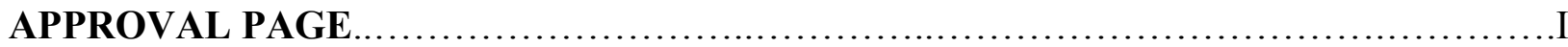

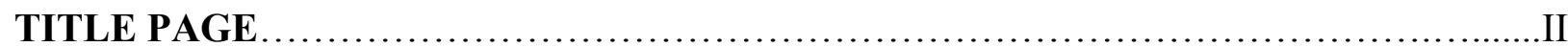

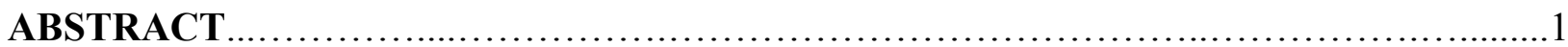

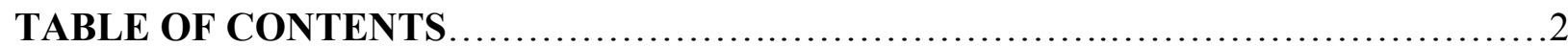

DEDICATION \& ACKNOWLEDGMENTS ..........................................

INTRODUCTION \& LITERATURE REVIEW ................................... $4-13$

* Forest History

* Forest Fragmentation/Deforestation

* Ecotones

* Forest Soils

* Microbial Diversity

METHODS.

* Site Description

* Soil Sampling

* DNA Extraction

* Gel Electrophoresis

* Polymerase Chain Reaction/PCR Purification

* Restriction Digest

* Terminal Restriction Fragment Length Polymorphism

RESULTS.

$.26-44$

* Environmental Variables

* Microbial Diversity/Richness

* Ordination

DISCUSSION

* Explain Results

* Problems

* Future Direction

* Conclusion/Summary

WORKS CITED. 


\section{DEDICATION}

This thesis is dedicated to my beloved parents, Ronnie and Nada Smith. I hope this accomplishment paves the road to the future you envisioned for me all those many years ago when you chose to give the gift of education.

\section{ACKNOWLEDGEMENTS}

I would like to express my sincere gratitude for the opportunity to work with Dr. Roland de Gouvenain, a scholar and a gentleman who was always available for advice and support. $\mathrm{He}$ conveyed a passion of adventure toward our research. Without his patience and guidance this thesis would not have been possible.

Completing my thesis was achieved through the help of the entire RIC Biology Department. I thank the following people for providing lab supplies, academic and technical support, motivation and encouragement: Dr. Edythe Anthony, Dr. Yael Avissar, Dr. Deborah Britt, Dr. Suzanne Conklin, Dr. Breea Govenar, Dr. Eric Hall, Mrs. Victoria Hittinger, Dr. Dana Kolibachuk, Dr. Lloyd Matsumoto, Mr. Louis McGowan, Dr. Thomas Meedel, Dr. Rebeka Merson, Dr. Eric Roberts, Mrs. Sharon Rogers and Dr. Sarah Spinette.

I specifically want to thank my committee members: Dr. Britt, Dr. Roberts, and Dr. Spinette for their assistance, positive criticism, and unbelievable patience. Words cannot express how thankful I am to have had the pleasure to work with you all.

I thank Dr. Mark Ashton and the Yale School of Forestry for permitting this research at the YaleMeyers forest and for creation of the gap.

This research is based in part upon work conducted using the Rhode Island Genomics and Sequencing Center, which is supported in part by the National Science Foundation (MRI Grant No. DBI-0215393 and EPSCoR Grant Nos. 0554548 \& EPS-1004057), the US Department of Agriculture (Grant Nos. 2002-34438-12688 and 2003-34438-13111), and the University of Rhode Island. Thanks to Paul Johnson and Janet Atoyan for offering their expertise in DNA analysis. Thanks to Dr. Rodrigue Spinette of the University of Rhode Island for helping with the DNA extraction and providing a positive control to run with my samples.

Thank you to my colleagues in the RIC Forest Ecology Lab who helped with this research, especially, Kiley Schultz, Eric Wood and Heather Boulanger. 


\section{INTRODUCTION \& LITERATURE REVIEW}

Forests are made up of numerous living organisms such as trees, shrubs, grasses, mosses, algae, arthropods, mammals, birds, reptiles, amphibians, as well as microbes that live on plants, on animals, and in the soil. The forest also is made up of important non-living components like fallen branches, logs, soil, water, and minerals. The interactions between these abiotic and biotic elements make up dynamic communities in forest biomes (Thomas \& Packham, 2007).

Globally, forests cover 4 billion hectares (ha), which is equivalent to $\sim 30 \%$ of the Earth's total land area (Adams, 2012). Forests are shaped over time by their climate, weather, land-use, and natural processes, and have provided shelter, food, medicine and wood to humans for millennia. In fact, forests have been so valuable that humans have overexploited them. About one half of the forests that once covered the Earth are now gone, the result of anthropogenic deforestation (Aber \& Foster, 2004; FAO, 2009).

Forests cover $60 \%$ of southern New England or 160,000 ha. The climate of southern New England was much colder 10,000 years ago, and the forests that established following the end of the last ice age resembled the spruce-fir forests that now occupy northern New England. As the climate warmed, the forests slowly evolved into an oak-hickory dominated ecosystem. The Native Americans of southern New England originally lived in these forests, where they could hunt game and harvest other sources of food like acorns and chestnuts, as well as raw materials for canoes, houses, and fuel. Controlled fires were set to remove the undergrowth, and to increase forage, which promoted deer and other game species to the area. When the soil lost its fertility, the land would be abandoned and this sequence would be repeated elsewhere, giving the old site time to regenerate (Butler et al., 2002; Widmann et al., 2004). 
Europeans settled in southern New England around the beginning of the $17^{\text {th }}$ century and lived off the land just like the Native Americans did with one crucial difference: the Native Americans were mobile while the colonists settled on a permanent area of land and utilized that land and the surrounding forest. This more intensive land use resulted in more forest area being cleared for farming and agriculture, and the remaining forest were turned into fields and pastures, and stripped of wood for fuel and lumber. The forest decreased to about a quarter of the state's area prior to the Industrial Revolution and southern New England's streams began to silt up causing the rivers to alternate between flooding and running dry. Some species of wildlife began to disappear with few deer remaining by the mid-1800s (Butler et al. 2002; McLoughlin, 1976).

The Industrial Revolution (1840) changed the landscape of southern New England. People moved to the cities for jobs, food was imported from the Midwest, and many farms were abandoned giving the forests a chance to regenerate. The New England Hurricane of 1938 and extensive forest fires destroyed many of the trees in these "old-field" forests. The forests then regrew into the forests we see today. Other factors like selective harvesting, diseases/pests, and changes in forest fire management, have also affected southern New England's forests (Abrams, 2003; Lorimer \& White, 2003).

Deforestation (the clearing of forests) can lead to forest fragmentation, which happens when large, contiguous forests are cut down, forming smaller, more isolated forest patches. Fragmentation causes the synchronized decline of forest area, the increase in forest edge, and the separation of large forest areas into smaller non-contiguous fragments. This process can create edge effects or edge influence (Broadbent et al. 2008; Cochrane, 2002; Clark \& Covey, 2012). These edge effects can lead to changes in everything from microclimate to species composition, and can extend deep into the remaining forest areas. Forest fragmentation is a global problem 
that results from natural disturbances (e.g. fire and disease), but the majority of fragmented forests around the world have been caused by anthropogenic activities (e.g. road construction, urbanization, agriculture, fire and logging) (Mourelle et al., 2001; Wade et al., 2003). The fragmentation of forests multiplies the linear quantity of forest-to-non-forest edges and affects the ecology and biodiversity of these forests (Harper et al. 2005; McDonald \& Urban 2004).

Forest edges are ecotones, or transitional zones between two adjacent ecosystems (Odum, 1971). Ecotones may contain greater species richness because they are made up of species from two bordering habitats plus ecotonal specialists (Ries et al., 2004). Some examples of natural ecotones include forest-to-grassland ecotones, forest-to-woodland ecotones, and forest-to-swamp ecotones (Hufkens et al., 2008). Clearing the forest or building a road creates man-made ecotones. Ecotones can be more subtle and exhibit microclimate gradients (for example, soil pH, soil temperature, and soil moisture) (McArthur, 1988). Figure 1 shows plant distribution across a serpentine-to-nonserpentine soil ecotone in southwestern Oregon (Ricklefs, 2001).

Soil is a mixture of minerals and organic particles of various sizes and composition, plus pores that contain air and water. Soils are at the surface of the earth and support plant life, mediate various ecosystem processes (nutrient cycling, storing carbon, and decomposing organic matter), and harbor many living communities. Soil life is diverse; one gram of soil can contain 10 billion microbes (organisms that can only be seen under a microscope and are smaller than $100 \mu \mathrm{m}$ ) of thousands of different species that carry out numerous processes (e.g. biogeochemical cycling of hydrogen $(\mathrm{H})$, carbon $(\mathrm{C})$, nitrogen $(\mathrm{N})$, phosphorus $(\mathrm{P})$, oxygen $(\mathrm{O})$, and sulfur $(\mathrm{S}))$ (Torsvik \& Ovreas, 2002; Wardle et al., 2004). 


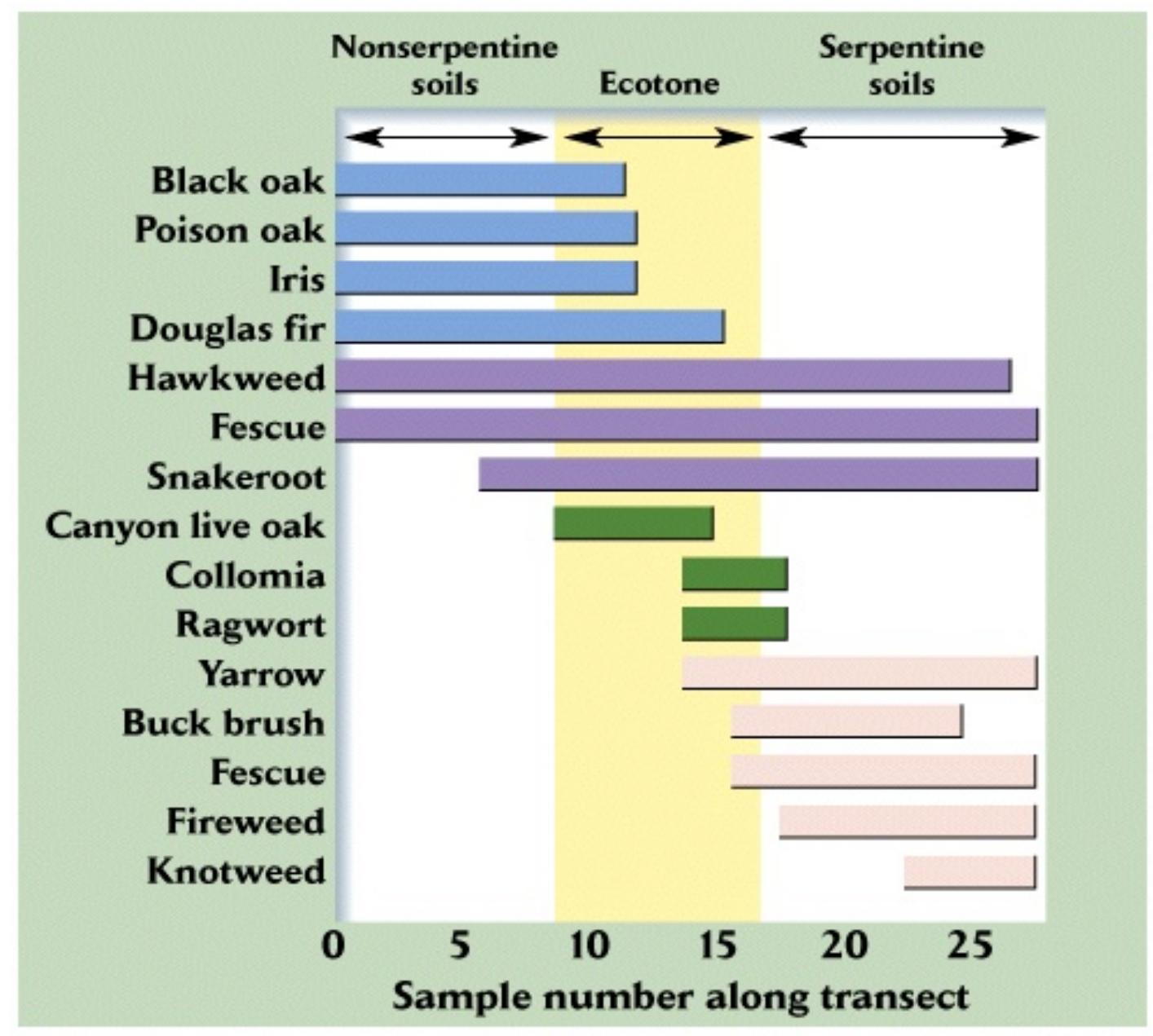

Figure 1 An ecotone between plant distributions across serpentine and nonserpentine soils in southwestern Oregon. The ecotone has higher $\alpha$ diversity than either the serpentine and nonserpentine soils. Levels of nickel, chromium, iron, and magnesium rise across the boundary into the serpentine soil; copper and calcium levels of the soil decrease. The edge of the serpentine soil marks the borders of many species that either cannot tolerate these soils, such as black oak, or are restricted to them, such as buckbush and fireweed. A few species, such as collomia and ragwort, exist only within the narrow zone of transition; others, such as hawkweed and fescue are not effected by differences in these soil minerals (Ricklefs, 2001). 
While many anthropogenic activities, such as development, agriculture, use of pesticides, and pollution can potentially influence soil microbial diversity, how these changes affect the belowground and aboveground ecosystems is not well known (Kirk et al. 2004; Van Horn, 2013). As soil organisms move through the soil they create channels that improve aeration and drainage. Nematodes and protozoa swim in the layer of water around soil particles and graze on bacteria, and fungi decompose soil organic matter. Microbes play key roles in nutrient cycling, as they break down organic matter to obtain energy, releasing essential nutrients and carbon dioxide in the process. Conditions that benefit soil life also support plant growth. A healthy, diverse population of soil microbes is correlated with a healthy, diverse ecosystem (Garbeva et al., 2004). A diverse microbial population can include aerobic and anaerobic microbes. Some soil microorganisms are photosynthetic primary producers, others are herbivores that feed on microbial primary producers, and still others feed on the herbivores (Ikeda et al., 2006).

The ability of an ecosystem to recover from a disturbance depends in part on the diversity of the soil microbial community (Muller et al., 2002), Microbes are a critical part of creating environmental conditions that support the life of the entire ecosystem by facilitating several process (e.g. promoting plant productivity, enhancing water relations, regulating nutrient mineralization, permitting decomposition, and acting as an environmental buffer), and biodiversity influences ecosystem stability, productivity, and resilience from stress and disturbances (Horner-Devine, 2003; Torsvik, 2002, Nannipieri, 2003; Neher, 1999). Studying soil microbes and their impact on ecological processes can contribute to better management of ecosystems under scenarios of increasing physical, chemical, and biotic disturbances caused by humans. Uncovering the links between the aboveground/belowground ecosystems can improve our ability to predict the effects of anthropogenic environmental/climate changes on biodiversity 
and ecosystem properties and can enhance the effectiveness of restoration and conservation efforts (Wall, 1999). Soil microbes regulate the nutrient supply available to plants, and some examples of the aboveground/belowground ecosystem relationships include food webs, mutualistic relationships, competitive links, multiple trophic levels, feedback loops and exchanges in energy and nutrients. (Wardle, 2002; Hooper et al., 2005; Kardol, 2010; van der Putten et al. 2009).

In southern New England, few studies have investigated the extent to which the aboveground part of the forest ecosystems affects the diversity of soil microbes (Wardle et al. 2013; Fierer \& Jackson, 2006). Forest gaps modify microclimates and impact soil processes and properties due to the removal of the trees allowing direct sun into the gap, hence increased temperature during the growing season. Soil moisture increases due to the removal of roots that are responsible for water uptake, all of which have direct impacts on soil microbial diversity (Castro et al. 2010 \& Scharenhbroch, 2007). To study forest fragmentation, researchers can create gaps in experimental forests. For the past seven years, the Rhode Island College Forest Ecology Lab has been investigating the response of different species of canopy trees to an edge-creating gap within an oak-hickory forest in the Yale-Myers Experimental Forest (Connecticut) by collecting data along $40 \mathrm{~m}$ transects from the gap edge to the forest interior. Those data have shown that canopy trees, following the creation of a gap in 2000 , responded to the gap edge by increasing their radial growth by a factor of 10 , depending on the species, but only within $10 \mathrm{~m}$ of the gap edge into the forest (Smith \& de Gouvenain, unpublished data).

While the soil microbiota is amazingly diverse, my study concentrates only on the bacterial community. Under a microscope, bacteria look like cocci (spheres), bacilli (rods) or spirilla (spiral). The traditional methods used to identify bacteria rely on phenotypic characterization 
(e.g., morphology and Gram staining) and an array of biochemical tests (e.g. enzymatic activity, carbohydrate utilization, and metabolic pathway analysis). Unfortunately, these tests only work for bacteria that have been grown in a pure culture, while the majority of microbes cannot be cultivated in a lab. To overcome this problem, sequence comparisons of the $16 \mathrm{~S}$ ribosomal RNA (rRNA) gene can be performed. Bacteria with similar 16S rRNA sequences are more closely related. There is no clear definition of what species means for bacteria. The biological species concept — that a species is a collection of individuals that can mate and produce fertile offspring - is not useful for bacteria because they reproduce asexually (Sokal \& Crovello, 1970). In this study, I will consequently use the term phylotype instead of species to describe related groups of bacteria that have the same 16S rRNA gene sequence.

The question that I investigated is how a forest-to-gap gradient influences soil bacterial diversity. Based on research done by Scharenhbroch et al. (2007), Harper et al. (2005), and Fierer \& Jackson (2006), I hypothesized that the edge will contain the most diverse bacterial community, followed by the gap, and then the forest. The edge should have the most bacterial diversity because edges are ecotonal habitats influenced by both the gap and the forest ecosystems, and potentially contain a greater diversity of ecological niches associated with both the gap and the forest. The gap should have greater bacterial diversity than the forest because gaps receive increased solar radiation and more moisture for reasons given above, which support faster bacterial reproduction (Salvador-Van Eysenrode, 2002; Scharenhbroch, 2007).

The terminal restriction fragment length polymorphism (TRFLP) method has been applied to a very diverse range of ecological investigations including bacterial surveys of almost every imaginable type of terrestrial and aquatic habitat. These studies allowed examination of how ecosystem management and global climate change may affect bacterial populations in a range of 
habitats, and the relationship between bacterial community composition and ecosystem functioning (Thies, 2007). In addition, the TRFLP method is ideal for analyzing a large number of samples and for quantitatively detecting differences in the diversity and composition of highly complex soil bacterial communities, even when the species are not known (Fierer, 2006). This method involves the amplification of the ubiquitous 16S rRNA gene by the polymerase chain reaction (PCR), followed by restriction enzyme digestion and capillary electrophoresis to separate DNA fragments by length. During capillary electrophoresis, the PCR products are electrokinetically injected into fused silica polyimide capillaries and a high voltage is applied causing the negatively charged fluorescent DNA fragments to migrate towards the positive electrode. As the fluorescently labeled DNA fragments migrate through the capillary they are separated by size. At the positive electrode they move through the path of a laser beam, which causes the dyes on the fragments to fluoresce. An optical detection device senses the fluorescence signals, which are converted to digital data. In TRFLP, fluorescent end-tagging of either the $5^{\prime}$ or $3^{\prime}$ oligonucleotide primer used in the PCR amplification allows sizing of terminal restriction fragments after PCR products have been hydrolyzed with a selected restriction enzyme, producing a molecular "fingerprint" characteristic of the soil community analyzed. A sizing curve is generated using the known DNA size standards and their respective migration times, and this curve is used to precisely determine the size of the unknown fragment (Gruntzig, $2002 \&$ Osborn, 2012).

The 16S rRNA gene is used as the target to be amplified in TRFLP analyses because it is part of the small subunit of the ribosome, which has changed little over the course of evolution, and the minor mutations that have occurred provide a basis for phylogenetic analysis. The 16S rRNA gene is ideal for community studies because it is found in all bacteria, but different regions of the 
gene have distinct levels of variability, including highly conserved regions that are similar in all organisms and other segments that differ greatly (Woese, 2000). The highly conserved regions are essential for designing PCR primers that can be used to amplify all 16 rRNA genes in samples of diverse microbial communities (referred to as complex samples) while the variable regions assist in differentiating one phylotype from another (Schloss \& Westcott, 2011).

Two measures of $\alpha$-diversity within a community are commonly used in combination: phylotype richness (S) and Simpson's index of diversity (D). S is simply the number of phylotypes present in a community. $\mathrm{D}$ is a mathematical measure of phylotype diversity in a community:

$$
D=\frac{1}{\sum_{i=1}^{S} p_{i}^{2}}
$$

where $\mathrm{S}$ is the number of phylotypes and $p_{i}$ is the portion of phylotype $i$ in the community. A community with the same number of individuals for each phylotype is considered to be even and would have a higher $\mathrm{D}$ than a community with different numbers of individuals in each phylotypes within the community shown by a lower D (Janda \& Abbott, 2007).

This study is useful because it examines how microbes respond to deforestation, more specifically, how microbial diversity is effected by anthropogenic environmental change. Understanding how microbes react to such changes is important because microbes are responsible for environmental processes that support life like the recycling of nutrients, the production of clean water, and the removal of pollutants. 


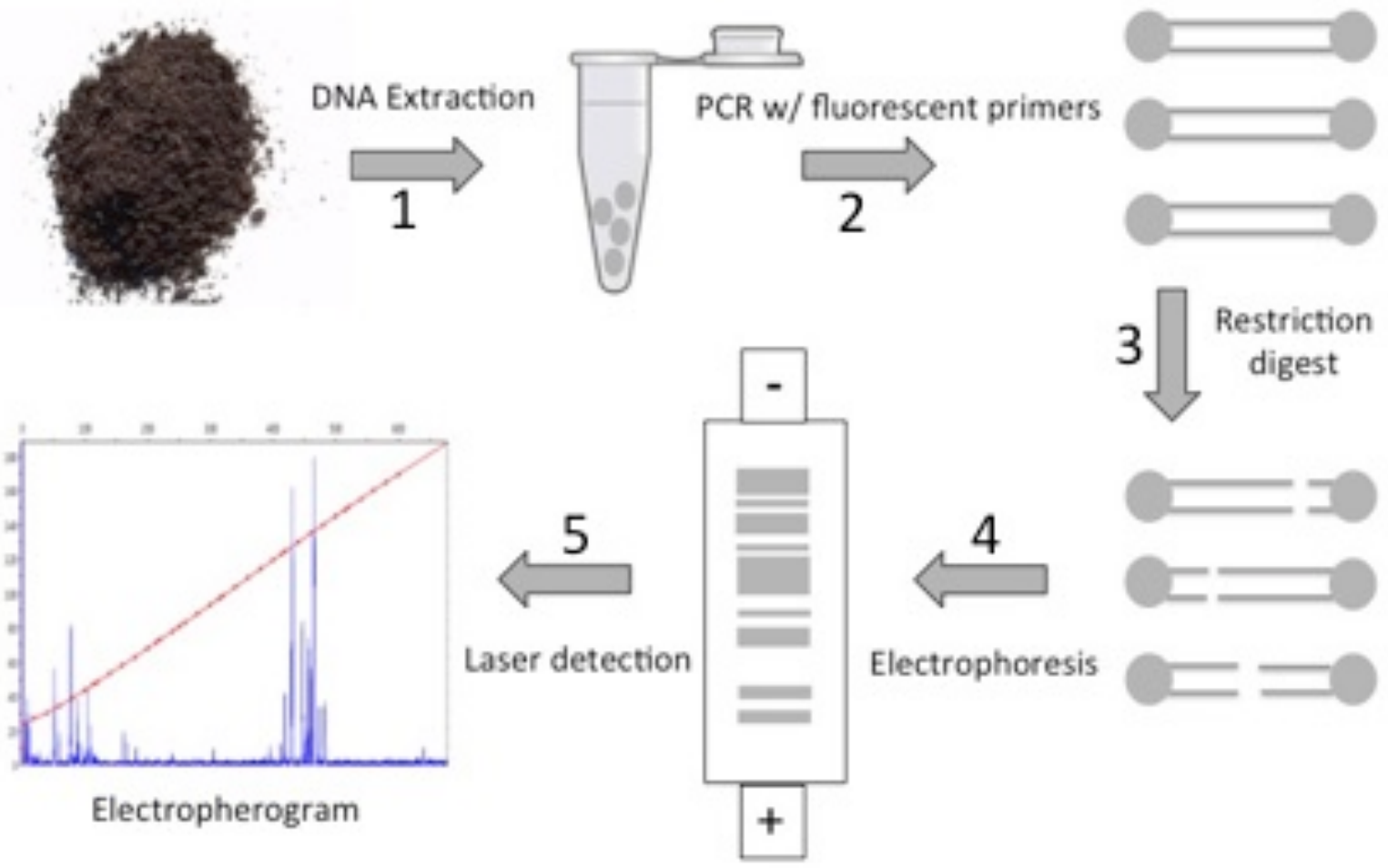

Figure 2 Flow chart of experimental methods. 1. DNA extraction from soil samples. 2. PCR amplification of $16 \mathrm{~S}$ rRNA with fluorescent primers. 3. Restriction enzyme digestion. 4. Separation of restriction fragments. 5. Laser detection on ABI genetic analyzer and electropherograms analysis. 


\section{METHODS}

\section{Study Site}

The Yale-Myers Experimental forest (northeastern Connecticut) is a 7,800-acre forest consisting of mixed hardwood, eastern white pine (Pinus strobus), and eastern hemlock (Tsuga canadensis) trees atop glacial till soils. It is owned and operated by the Yale School of Forestry and Environmental Studies (Fig. 3). The average temperature is $8.75^{\circ} \mathrm{C}$, the average annual snowfall is $1.23 \mathrm{~m}$, and the average annual precipitation is $1.20 \mathrm{~m}$. Large seasonal temperature differences are typical with hot summers (temperatures surpassing $32{ }^{\circ} \mathrm{C}$ ) and cold winters $\left(-3{ }^{\circ} \mathrm{C}\right)$ scattered with rain and snow. In the winter of 1999-2000, the Yale University Forestry staff created two 20 $\mathrm{x} 110 \mathrm{~m}$ experimental large gaps oriented east-west in two different locations by removing and clearing out all above-ground biomass (trees, shrubs and seedlings) with minimum disturbance to the soil. In 2007, the RIC Forest Ecology Lab set up four $30 \mathrm{~m}$ belt transects that start on the northern edge and run perpendicular from the edge into the forest. This study was conducted at the Tree Heaven Gap, and each transect was extended by $10 \mathrm{~m}$ into the gap creating $40 \mathrm{~m}$ transects (transect labels: T2, T5, T9, and T12) (Fig. 4). Soil samples were collected from all four transects at $10 \mathrm{~m}$ intervals starting inside the gap and extending $30 \mathrm{~m}$ into the forest (40 m total) for a total of 5 sampling locations (henceforth "distances") per transect. At each distance along each transect, one soil sample was collected for gravimetric water moisture data, and two (pseudoreplicated) soil samples were collected to measure bacterial diversity. A total of 60 soil samples were collected, 3 samples per distance for each transect (see below for soil sampling details). For each transect, sample D1 was in the gap (-10 m), sample D2 was at the edge of the gap $(0 \mathrm{~m})$, sample D3 was located $10 \mathrm{~m}$ into the forest, sample D4 was $20 \mathrm{~m}$ into the forest, and sample D5 was 30 meters away from the edge (Fig. 4). 


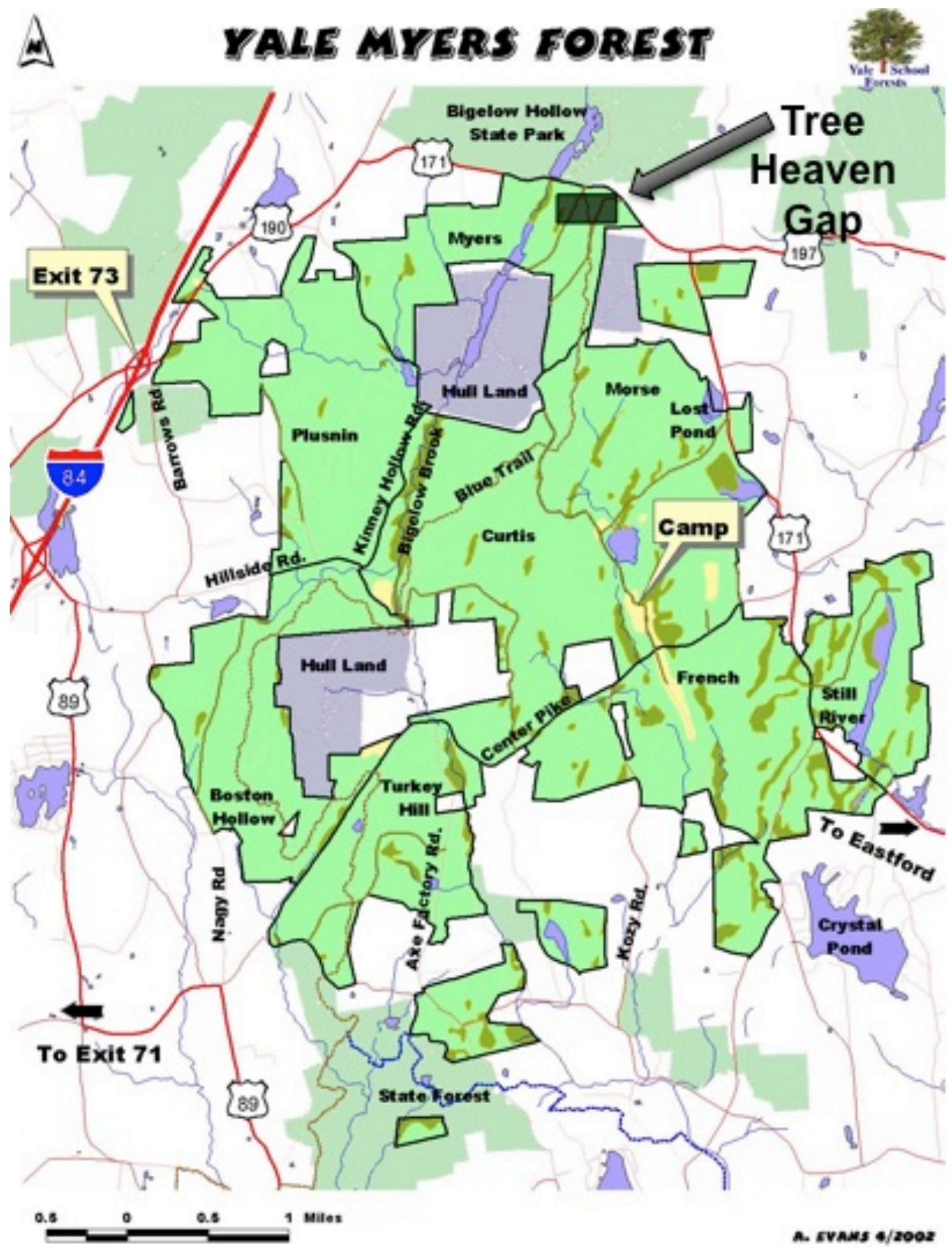

Figure 3 Map of Yale Myers Forest showing Tree Heaven Gap (eastfordconservation.org). 


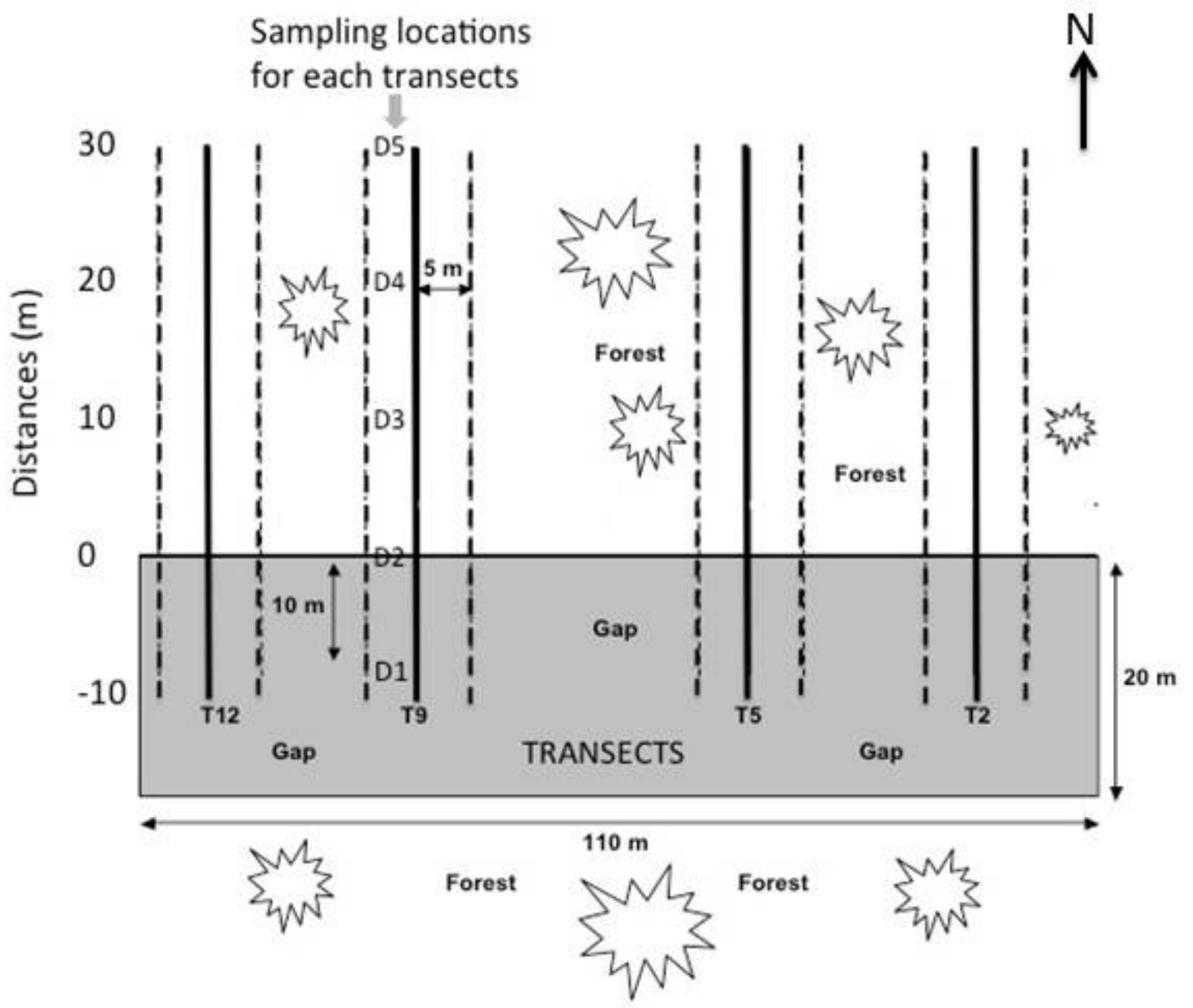

Figure 4 Map of Transects. Soil samples were collected from all transects (T2, T5, T9 \& T12) at each distance: D1 (-10m; gap), D2 (0m, edge), D3 (10m, forest), D4 (20m, forest \& D5 (30m, forest).

\section{Soil Sampling:}

Soil samples were collected by first removing the litter layer and driving a soil probe that was 30 $\mathrm{cm}$ long and $12.7 \mathrm{~mm}$ diameter into the ground, collecting soil from the $\mathrm{O}$ and $\mathrm{A}$ horizons.

Disrupting the soil as little as possible, the soil sample was removed from the probe and wrapped with aluminum foil, keeping the soil cylinder intact. The wrapped soil was then flash-frozen by 
dipping it into a dewar of liquid nitrogen $\left(-196{ }^{\circ} \mathrm{C}\right)$ for 4 seconds on each side, placed in a labeled Ziploc Double Zipper Freezer Bag, and put in a cooler with ice until the samples were able to be transferred to a $-80{ }^{\circ} \mathrm{C}$ freezer. These samples were placed in a soil collection bag and put directly in the cooler. To calculate the percent gravimetric water moisture, I massed beakers on a scale, added the soil, and put them in a drying oven for 38 hours at $45^{\circ} \mathrm{C}$, and then reweighed them. I used the following formula: percent gravimetric water moisture $=$ (moist soil weight - dry soil weight)/dry soil weight $\times 100 \%$. To measure soil $\mathrm{pH}$ in the field I inserted a Kelway soil tester $7 \mathrm{~cm}$ into the ground, and recorded $\mathrm{pH}$ after 30 seconds. The average mass of soil samples collected was 95 grams.

\section{DNA Extraction}

DNA was extracted using the Powersoil DNA Isolation kit from MOBIO laboratories, Inc. which uses patented Inhibitor Removal Technology (IRT) to isolate microbial genomic DNA from all soil types (Fig. 5). I followed MOBIO's protocol, with a few minor changes suggested by Dr.

Rodrigue Spinette (University of Rhode Island). First, $250 \mathrm{mg}$ of each soil sample was added to a bead beating tube and vortexed for 5 seconds for rapid and complete homogenization. Then, I added $60 \mu \mathrm{L}$ of solution $\mathrm{C} 1$, which contains sodium dodecyl sulfate (SDS), an anionic detergent that solubilizes fatty acids and lipids of the cell membrane for cell lysis, and vortexed for 5 seconds. Next, I heated the tubes to $70{ }^{\circ} \mathrm{C}$ for 5 minutes, vortexed at maximum speed $(3,200$ rpm) for 10 minutes and then heated the samples to $70{ }^{\circ} \mathrm{C}$ for 3 minutes and vortexed for another 5 seconds. The tubes were centrifuged for 30 seconds at 13,000 rpm (all centrifugation steps were performed at this speed), and the supernatant was transferred to a clean centrifuge tube to which $250 \mu \mathrm{L}$ of solution $\mathrm{C} 2$, which contains a reagent to precipitate non-DNA organic and 
inorganic material including humic substances, cell debris, and proteins, was added and tubes were vortexed for 5 seconds. I then incubated the samples at $4{ }^{\circ} \mathrm{C}$ for 5 minutes, centrifuged for another minute, transferred the supernatant to a clean centrifuge tube and added $200 \mu \mathrm{L}$ of solution $\mathrm{C} 3$, another reagent that precipitates additional non-DNA organic and inorganic material. After vortexing the samples for 5 seconds, they were incubated at $4{ }^{\circ} \mathrm{C}$ for 5 minutes and centrifuged for 1 minute. The supernatant was transferred to a clean $2 \mathrm{ml}$ round bottom centrifuge tube, and $1200 \mu \mathrm{L}$ of $\mathrm{C} 4$ was added and vortexed for 5 secsonds. $\mathrm{C} 4$ is a salt solution that enables the DNA to bind tightly to the silica membrane of the spin filter (included in the extraction kit). The spin filter was loaded with $675 \mu \mathrm{L}$ of the mix and centrifuged for 1 minute. The flow-through was discarded and the filter reloaded and centrifuged again. The silica filter membrane was then washed with $500 \mu \mathrm{L}$ of Solution C5, an ethanol based solution. This wash solution removes residual salt, humic acid, and other contaminants while the DNA stays bound to the silica membrane. After centrifugation for 30 seconds, the flow through was discarded, and the tubes were centrifuged for an additional 1 minute (in order to completely remove the ethanol from the membrane), and the spin filter was transferred to a clean centrifuge tube. Next, $100 \mu \mathrm{L}$ of solution C6 (elution buffer) was added to the center of the filter, making sure to soak the entire membrane resulting in a more efficient and complete release of the DNA from the silica Spin Filter membrane followed by centrifugation for 1 minute. As solution C6 passed through the silica membrane, bound DNA was selectively released. The filters were discarded and I stored the eluted DNA extract at $-20{ }^{\circ} \mathrm{C}$. 


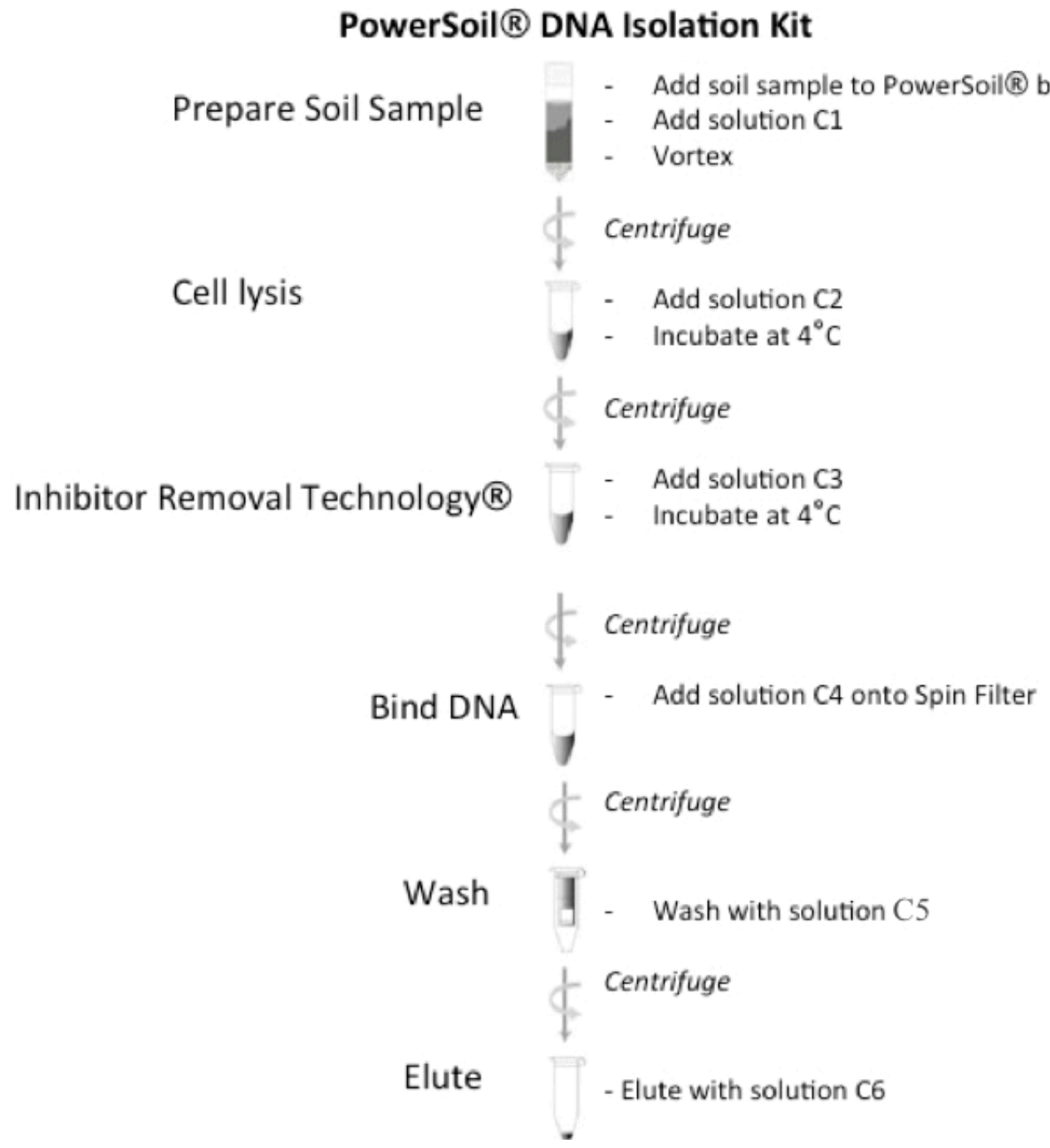

Figure 5: Flowchart of DNA Extraction (MO BIO Laboratories, Inc.)

\section{Gel Electrophoresis:}

To visualize the extracted DNA I ran a 1\% agarose gel on a FisherBiotech Electrophoresis MiniHorizontal Unit. Following a protocol from Dr. Eric Roberts (RIC), I assembled the gel mold by first rotating the gel bed so the orange gaskets were facing the side of tank and pushed it gently into place, and then I inserted the comb to make the lanes and leveled the gel box. I prepared a $1 \%(\mathrm{w} / \mathrm{v})$ agarose gel by mixing $30 \mathrm{ml}$ Tris-borate-EDTA (TBE) buffer with $0.30 \mathrm{~g}$ agarose in 
$125 \mathrm{~mL}$ Erlenmeyer flask, and microwaved it for 1 minute to dissolve the agarose. Next, I added $1 \mu \mathrm{L}$ of $0.5 \mu \mathrm{g} / \mathrm{ml}$ ethidium bromide (etbr) to dye the DNA. Once the gel cooled down, I poured it into the bed and let it solidify. Once the gel was solid, I prepared the gel for loading, by gently lifting out the gel bed with the solidified gel, rotated it $180^{\circ}$, and placed it in the electrophoresis unit with the wells closest to the black (negative) electrode. I then added enough TBE buffer so that the wells were covered and removed the comb and loaded my samples into the gel. First, I pipetted $2 \mu \mathrm{L}$ of loading buffer (6x) onto a piece of Parafilm and pipetted $10 \mu \mathrm{L}$ of the DNA sample into the drop of loading buffer and mixed them together by pipetting up and down a few times, and then I loaded the sample into a well of the gel. $2 \mu \mathrm{L}$ of the Stratagene Kb Molecular Weight marker and $8 \mu \mathrm{L}$ deionized (DI) $\mathrm{H}_{2} \mathrm{O}$ was mixed with $2 \mu \mathrm{L}$ loading buffer, which was then loaded into the gel. I ran the gel from the black anode to red cathode at a constant voltage (100mV) for 40 minutes. To visualize bands I used a Syngene UV box.

\section{DNA Concentration}

To measure the concentration of the DNA samples I used the Synergy HT Multi-Mode Microplate Reader (Biotek, Inc.) To blank the machine, I added $2 \mu \mathrm{L}$ of the elution buffer from the PowerSoil DNA Isolation kit to wells A1 and A2. Then I added $2 \mu \mathrm{L}$ of each sample to the remaining wells.

\section{Polymerase Chain Reaction}

I used PCR to amplify the $16 \mathrm{~S}$ rRNA gene by several orders of magnitude. I ordered custom primers, which were complementary to the conserved region of the bacterial 16S rRNA gene from Invitrogen Inc., that were designed by Fierer and Jackson (2006). The reverse primer was 
designated Univ1492r (5'-GGTTACCTTGTTACGACTT- 3'), and the forward primer had a fluorescent HEX tag from Applied Biosystems on the 5' end and was designated Bac8f (5'AGAGTTTGATCCTGGCTCAG-3'). I resuspended the lyophilized primers in deionized water such that a $100 \mu \mathrm{M}$ stock solution was created. A portion of this stock was diluted to create working solutions of $25 \mu \mathrm{M}$. I used the HotStarTaq Master Mix Kit from Qiagen Inc. to perform the PCR. Each $40 \mu \mathrm{L}$ PCR mixture contained $20 \mu \mathrm{L}$ of HotStarTaq 2x Master Mix (Qiagen), 4 $\mu \mathrm{L}$ of each primer $(0.5 \mu \mathrm{M}), 2 \mu \mathrm{L}$ of BSA $(1 \mathrm{mg} / \mathrm{ml})$, and $6 \mu \mathrm{L}$ of DI $\mathrm{H}_{2} \mathrm{O}$ and $4 \mu \mathrm{L}$ DNA (50 80ng), and loaded the tubes into the Eppendorf Mastercycler pro PCR machine. The initial denaturation step was $95^{\circ} \mathrm{C}$ for 15 minutes, and each of the 35 PCR cycles consisted of $60 \mathrm{~s}$ at $94{ }^{\circ} \mathrm{C}, 30 \mathrm{~s}$ at $42{ }^{\circ} \mathrm{C}$, and $60 \mathrm{~s}$ at $72{ }^{\circ} \mathrm{C}$.

After PCR was complete, I ran a $1 \%$ agarose gel with $10 \mu \mathrm{L}$ of the PCR reaction with the positive control, which was a sample of bacterial 16S rRNA PCR amplified by Dr. Rodrigue Spinette (URI). All samples were compared to the size of the control fragment, which had a known molecular weight of 1.5 kilobases $(\mathrm{kb})$. If the bands did not align with the control band, this implied that I had not amplified the 16S rRNA gene and I repeated the DNA extraction until I achieved PCR products that were $1.5 \mathrm{~kb}$.

\section{PCR purification}

PCR products $(20 \mu \mathrm{L})$ were purified with a QIAquick PCR Purification kit from Qiagen Inc. following the recommended protocol. First, I added $125 \mu \mathrm{L}$ of buffer PB, which allows efficient binding of single- or double-stranded PCR products as small as $100 \mathrm{bp}$ and the removal of primers up to 40 nucleotides long, to $20 \mu \mathrm{L}$ of PCR reaction and mixed. Then I placed the QIAquick column in to a $2 \mathrm{ml}$ collection tube. To bind the DNA, I applied the sample to the 
QIAquick column and centrifuged for 1 minute. I discarded the flow-through and placed the QIAquick column back in the same tube. I added $0.75 \mathrm{ml} \mathrm{Buffer} \mathrm{PE} \mathrm{(containing} \mathrm{ethanol)} \mathrm{to}$ wash away dNTPs, primers and other non-PCR products to the QIAquick column and centrifuged for 1 minute. Next, I centrifuged the QIAquick column once more in the $2 \mathrm{ml}$ collection tube for 1 minute to remove the residual wash buffer. Then, I placed each QIAquick column in a clean $1.5 \mathrm{ml}$ microcentrifuge tube. To elute the DNA, I added $30 \mu \mathrm{L}$ Buffer EB (10 $\mathrm{mM}$ Tris $\cdot \mathrm{Cl}, \mathrm{pH} 8.5)$ to the center of the QIAquick membrane and centrifuged the column for 1 minute. $6 \mu \mathrm{L}$ of the purified DNA was then ran on a $1 \%$ agarose gel to check for DNA bands and stored at $4{ }^{\circ} \mathrm{C}$.

\section{Restriction Digest}

The purified DNA was split into two separate restriction digests to generate the fluorescently labeled terminal restriction fragments by using the restriction endonuclease HhaI and RsaI, both enzymes were extracted from an E. coli strain and were purchased from New England Bio Labs, Inc. Hhal's recognition sequence is $5^{\prime} \ldots G_{C G}{ }^{\downarrow} \mathrm{C} \ldots 3^{\prime}$, and Rsal's recognition sequence is $5^{\prime} \ldots \mathrm{GT}^{\Downarrow} \mathrm{AC} \ldots 3^{\prime}$. I Digested $40 \mathrm{ng}$ of the amplified DNA, which included those produced from my soil samples and the positive control amplicon from R. Spinette, with $4 \mathrm{U}$ enzyme (1U is defined as the amount of enzyme required to digest $1 \mu \mathrm{g}$ of DNA in 1 hour at $37^{\circ} \mathrm{C}$ in a total reaction volume of $50 \mu \mathrm{l}$ ) in a $20 \mu \mathrm{L}$ reaction. I also digested the positive control. I incubated the samples at $37{ }^{\circ} \mathrm{C}$ for 1 hour to confirm complete digestion of terminal fragments, but not overdigestion. The enzyme was deactivated by heating the samples to $65^{\circ} \mathrm{C}$ for 20 minutes on a heating block. The Restriction Digest Master Mix for HhaI included $0.4 \mu \mathrm{L}$ of the enzyme, 2.0 $\mu \mathrm{L}$ of the 10X buffer, $0.2 \mu \mathrm{L}$ BSA $(1 \mathrm{mg} / \mathrm{ml}), 11.6 \mu \mathrm{L}$ DNA and $5.8 \mathrm{DI} \mathrm{H}_{2} \mathrm{O}$. The Restriction 
Digest Master Mix for RsaI included $0.4 \mu \mathrm{L}$ of the enzyme, $2.0 \mu \mathrm{L}$ of the $10 \mathrm{X}$ buffer, $6.2 \mu \mathrm{L}$ DI $\mathrm{H}_{2} \mathrm{O}$ and 11.4 DNA. The enzyme was deactivated by heating the samples to $65^{\circ} \mathrm{C}$ for 20 minutes on a heating block. $8 \mu \mathrm{L}$ of the digested DNA samples were ran on a $1 \%$ agarose gel to check for DNA bands and stored at $4{ }^{\circ} \mathrm{C}$.

\section{DNA Concentration}

To measure the concentration of my digested DNA samples I used the Synergy HT Multi-Mode Microplate Reader (Biotek, Inc.) To blank the machine, I added $2 \mu \mathrm{L}$ of the elution buffer from the PCR protocol to wells A1 and A2. Then I added $2 \mu \mathrm{L}$ of each sample to the remaining wells.

\section{Terminal Restriction Fragment Length Polymorphism}

PelletPaint NF co-precipitant from EMD Millipore, Inc. was used to further purify my digested DNA samples by removing salts. First, I thawed the PelletPaint and $3 \mathrm{M}$ NaAcetate and allowed it to reach room temperature. I also thawed the Hi-Di formamide (Life Technologies, Inc.), which is a deionized formamide used to resuspended samples before electrokinetic injection on capillary electrophoresis systems. Next, I added $2 \mu \mathrm{L}$ PelletPaint to the sample, followed by $3 \mu \mathrm{L}$ $3 \mathrm{M}$ NaAcetate. Then I added $20 \mu \mathrm{L}$ of $100 \%$ ethanol and vortexed briefly. I incubated the tubes at room temperature for 2 minutes, and then spun the samples in microcentrifuge at 13,000 rpm for 5 minutes to collect the DNA into a dark blue pellet that was visible at the bottom of the tube. I removed as much of the supernatant as possible without disturbing the blue DNA pellet. Next, I washed the pellet with $500 \mu \mathrm{L}$ of $70 \%$ ethanol, vortexed briefly and centrifuged at 13,000 rpm for 5 minutes and removed the supernatant. After repeating this wash step, I washed the pellet with $100 \%$ ethanol, vortexed briefly and spun at 13,000 rpm for 5 minutes and removed the 
supernatant (repeated this step 2 times). To dry the pellet, I incubated the samples at $65^{\circ} \mathrm{C}$ for several minutes until all the ethanol evaporated.

To make the Hi-Di formamide/size standard master mix for my digested samples, I added $24 \mu \mathrm{L}$ formamide with $1 \mu \mathrm{L}$ GeneScan 600 LIZ Size Standard, Applied Biosystems per samples. Next, I dissolved the pellet in Hi-Di formamide to the appropriate concentration (40 ng). Then I transferred $12 \mu \mathrm{L}$ of the mix with the dissolved pellet to strip tubes where they were later denatured and then analyzed on a $3130 x L$ Genetic Analyzer, (Applied Biosystems) at the University of Rhode Island's Genomics and Sequencing Center. The 3130xL Genetic Analyzer is a fluorescence-based genetic analysis system and the latest generation of 16-capillary electrophoresis instruments.

\section{Data Analysis}

I visualized the DNA profiles in the form of electropherograms using Peak Scanner v1.0 software from Applied Biosystems, which allowed me to perform DNA fragment analysis, and to compare bacterial community data from different samples. When reading the electropherograms, the $\mathrm{x}$-axis represents fragment length, which is a measurement of molecular weight in bp, and is diagonstic of different phylotypes. This bp number is the phylotype's ID. The y-axis is the peak height measured in Relative Fluorescent Units (RFUs) or intensity. This number represents the frequency of a given phylotype in the sample.

A one-way analysis of variance (ANOVA) was used to determine if there was a significant difference between the environmental variables (soil $\mathrm{pH}$, soil temperature and soil moisture) measured at each distance (D1 -D5). The Null Hypothesis was $\mathrm{H}_{0}$ : means of the environmental variables (soil $\mathrm{pH}$, soil temperature and soil moisture) are equal at D1-D5. 
Phylotype richness (S) was calculated by counting the number of phylotypes present in a community, and phylotype diversity was calculated using Simpson's index of diversity (D)

$$
D=\frac{1}{\sum_{i=1}^{S} p_{i}^{2}}
$$

where $\mathrm{S}$ is the number of phylotypes and $p_{i}$ is the portion of phylotype $i$ in the community. To examine the relationship between bacterial phylotype diversity and the variability in the environmental variables measured (soil temperature, soil $\mathrm{pH}$ and soil moisture), I used a multivariate direct gradient analysis technique called canonical correspondence analysis, or CCA (ter Braak, 1986). The two-dimensional ordination computed using PC-ORD summarizes the relationship between soil environmental conditions and the frequencies of the various phylotypes in a given sample from the different distances (D1-D5). For each ordination, I tested the Null Hypothesis $\mathrm{H}_{\mathrm{o}}$ : no relationship between the main matrix (phylotype matrix) and the environment matrix with a Monte Carlo (randomization) test, which measures how the observed CCA eigenvalues (a number that is derived from a square matrix) and phylotype-environment correlations compare with those from randomized CCA runs using the same matric cell values randomly re-assorted. The resulting test $p$-values ( $p=$ probability of Type I error) for different combinations of site variables were then used to determine which site variables best predicted the structure of the phylotype matrix. PC-ORD also computed a correlation analysis called a cluster dendrogram showing the relationships among the distances (D1-D5) as branches and nodes with the more similar distances connected with shorter branches, analogous to a phylogenic tree (de Gouvenain, and Silander 2003). 


\section{RESULTS}

Gap Effect on Soil Abiotic Components:

Early spring soil pH was slightly acidic throughout the study site, but the gap was less acidic than at all other distances (Table 1). There were no statistically significant differences in $\mathrm{pH}$ among the different distances (ANOVA; $F=0.445 ; \mathrm{p}=0.774)($ Table 2$)$.

Table 1 Soil pH Measured in Field on March 30, 2013

Distances

\begin{tabular}{lccccc}
\hline Transect & $\begin{array}{c}\text { D1 } \\
\text { (GAP,10m) }\end{array}$ & $\begin{array}{c}\text { D2 } \\
\text { (EDGE,0m) }\end{array}$ & $\begin{array}{c}\text { D3 } \\
\text { (FOREST,10m) }\end{array}$ & $\begin{array}{c}\text { D4 } \\
\text { (FOREST,20m) }\end{array}$ & $\begin{array}{c}\text { D5 } \\
\text { (FOREST,30m) }\end{array}$ \\
\hline T2 & 6.2 & 6.1 & 5.9 & 5.6 & 6.1 \\
T5 & 6 & 5.5 & 5.1 & 6 & 6.1 \\
T9 & 5.8 & 5.5 & 5.6 & 5.9 & 6 \\
T12 & 5.5 & 5.6 & 5.5 & 5.1 & 4.9 \\
MEAN & 5.9 & 5.7 & 5.5 & 5.7 & 5.8 \\
\hline
\end{tabular}

Table 2 One Way ANOVA of Soil pH data

\begin{tabular}{lccccc}
\hline & Sum of Squares & $\mathrm{df}$ & Mean Square & $\mathrm{F}$ & $p$-value \\
\hline Between Groups & .280 & 4 & .070 & .445 & .774 \\
Within Groups & 2.360 & 15 & .157 & & \\
Total & 2.640 & 19 & & & \\
\hline
\end{tabular}

Early summer gravimetric water moisture was similar throughout the study site, but on average, soil moisture was highest in the gap and soil water moisture decreased as distance into the forest increased (Table 3). There were no statistically significant differences among the means of the gravimetric water moisture data at each distance (ANOVA; $F=0.631 ; p=0.648)$ (Table 4). 
Table 3 Gravimetric Soil Water Moisture Measured on June 27, 2011

\begin{tabular}{lccccc}
\multicolumn{6}{c}{ Distances } \\
\hline Transect & $\begin{array}{c}\text { D1 } \\
\text { (GAP,10m) }\end{array}$ & $\begin{array}{c}\text { D2 } \\
\text { (EDGE,0m) }\end{array}$ & $\begin{array}{c}\text { D3 } \\
\text { (FOREST,10m) }\end{array}$ & $\begin{array}{c}\text { D4 } \\
\text { (FOREST,20m) }\end{array}$ & $\begin{array}{c}\text { D5 } \\
\text { (FOREST,30m) }\end{array}$ \\
\hline T2 & 42 & 34 & 30 & 30 & 46 \\
T5 & 64 & 42 & 66 & 46 & 26 \\
T9 & 51 & 57 & 43 & 34 & 29 \\
T12 & 29 & 30 & 34 & 35 & 38 \\
MEAN & 46.5 & 40.8 & 43.3 & 36.3 & 34.8 \\
\hline
\end{tabular}

Table 4 One Way ANOVA of Soil Moisture data

\begin{tabular}{lccccc}
\hline & Sum of Squares & df & Mean Square & $\mathrm{F}$ & $p$-value \\
\hline Between Groups & 378.200 & 4 & 94.550 & .631 & .648 \\
Within Groups & 2246.000 & 15 & 149.733 & & \\
Total & 2624.200 & 19 & & & \\
\hline
\end{tabular}

Early spring temperature was similar thought the study site with the lowest soil temperature in the gap (Table 5), but the difference was not statistically significant among distances (ANOVA; $F=0.043 ; p=0.996)($ Table 6$)$

Table 5 Soil Temperature $\left({ }^{\circ} \mathrm{C}\right)$ Measured on March 30, 2013 at $7 \mathrm{~cm}$ depth

Distances

\begin{tabular}{lccccc}
\hline Transect & $\begin{array}{c}\text { D1 } \\
\text { (GAP,10m) }\end{array}$ & $\begin{array}{c}\text { D2 } \\
\text { (EDGE,0m) }\end{array}$ & $\begin{array}{c}\text { D3 } \\
\text { (FOREST,10m) }\end{array}$ & $\begin{array}{c}\text { D4 } \\
\text { (FOREST,20m) }\end{array}$ & $\begin{array}{c}\text { D5 } \\
\text { (FOREST,30m) }\end{array}$ \\
\hline T2 & 10.0 & 10.2 & 10.0 & 9.8 & 9.5 \\
T5 & 14.5 & 15.5 & 14.7 & 14.5 & 15.3 \\
T9 & 10.0 & 10.0 & 11.0 & 10.3 & 10.2 \\
T12 & 9.3 & 10.0 & 10.8 & 10.7 & 9.8 \\
MEAN & 10.95 & 11.43 & 11.63 & 11.33 & 11.20 \\
\hline
\end{tabular}


Table 6 One Way ANOVA of Soil Temperature Data

\begin{tabular}{lccccc}
\hline & Sum of Squares & $\mathrm{df}$ & Mean Square & $\mathrm{F}$ & $p$-value \\
\hline Between Groups & 1.017 & 4 & .254 & .043 & .996 \\
Within Groups & 88.973 & 15 & 5.932 & & \\
Total & 89.990 & 19 & & & \\
\hline
\end{tabular}

Phylotype richness and diversity were computed from the capillary electrophoresis results, which were graphed as electropherograms. I ran into some complications that gave me very low intensity on a number of electropherograms from the restriction digests, but more so with those samples cut with restriction enzyme HhaI. Instead of analyzing an unequal sample size for each distance, I selected the electropherograms with the fragments cut by RsaI because this enzyme had the most complete dataset. I randomly selected four out of twenty electropherograms per distance and averaged the phylotype intensities to calculate phylotype richness and diversity (see discussion for more details). Figures 6-10 are comparison of the TRFLP patterns from the Yale Myers forest. The peaks indicate number of fragments from the measured TRFLP with the RsaI enzyme and a threshold cut-off of 50 fluorescence units.

Table 7 is the average of all electropherograms and the main phylotype intensity matrix used for the CCA ordination; it shows which phylotypes where found along the gap-to-forest transects, and their intensities. For instance, P463 (phylotype with molecular weight of 463) was found only at the edge, while P8 (phylotype with molecular weight of 8 ) was found at the gap and at the edge, and P104 was found everywhere except in the gap. There are also a number of 
phylotypes (P51, P78, P429, P431, and P447) that were found living at every distance (D1-D5) in the Yale Myers Forest, perhaps representing generalist bacteria not affected by the gap-toforest gradient.

Table 7: Phylotype Intensity Matrix (RFUs)

\begin{tabular}{llllllllllllll} 
& \multicolumn{1}{l}{$\mathbf{P 7}$} & $\mathbf{P 8}$ & $\mathbf{P 5 1}$ & $\mathbf{P 5 2}$ & $\mathbf{P 5 9}$ & $\mathbf{P 7 4}$ & $\mathbf{P 7 8}$ & $\mathbf{P 8 8}$ & $\mathbf{P 9 8}$ & $\mathbf{P 1 0 4}$ & $\mathbf{P 1 0 8}$ & $\mathbf{P 1 0 9}$ & $\mathbf{P 1 6 2}$ \\
\hline D1 & 0 & 61 & 59 & 0 & 62 & 88 & 72 & 0 & 0 & 0 & 57 & 58 & 84 \\
D2 & 0 & 152 & 97 & 0 & 77 & 0 & 168 & 83 & 0 & 115 & 0 & 0 & 0 \\
D3 & 0 & 0 & 76 & 0 & 110 & 0 & 125 & 75 & 0 & 54 & 0 & 0 & 0 \\
D4 & 64 & 0 & 92 & 0 & 73 & 0 & 97 & 106 & 0 & 98 & 0 & 74 & 0 \\
D5 & 0 & 0 & 60 & 64 & 63 & 0 & 71 & 58 & 53 & 61 & 0 & 0 & 0 \\
& & & & & & & & & & & & & \\
\hline & $\mathbf{P 1 6 9}$ & $\mathbf{P 4 1 8}$ & $\mathbf{P 4 1 9}$ & $\mathbf{P 4 2 8}$ & $\mathbf{P 4 2 9}$ & $\mathbf{P 4 3 0}$ & $\mathbf{P 4 3 1}$ & $\mathbf{P 4 4 7}$ & $\mathbf{P 4 4 8}$ & $\mathbf{P 4 5 4}$ & $\mathbf{P 4 5 6}$ & $\mathbf{P 4 5 7}$ & $\mathbf{P 4 5 9}$ \\
\hline D1 & 0 & 0 & 0 & 0 & 70 & 61 & 74 & 74 & 0 & 56 & 73 & 75 & 57 \\
D2 & 0 & 80 & 101 & 0 & 116 & 0 & 195 & 195 & 0 & 54 & 185 & 227 & 98 \\
D3 & 61 & 104 & 0 & 0 & 206 & 126 & 203 & 190 & 74 & 55 & 0 & 0 & 61 \\
D4 & 0 & 0 & 107 & 0 & 112 & 0 & 131 & 109 & 0 & 89 & 100 & 0 & 0 \\
D5 & 0 & 0 & 58 & 99 & 98 & 0 & 96 & 102 & 0 & 0 & 98 & 87 & 0 \\
& & & & & & & & & & & & & \\
& $\mathbf{P 4 6 0}$ & $\mathbf{P 4 6 1}$ & $\mathbf{P 4 6 3}$ & $\mathbf{P 4 6 4}$ & $\mathbf{P 4 6 5}$ & $\mathbf{P 4 6 6}$ & $\mathbf{P 4 7 4}$ & $\mathbf{P 4 8 2}$ & $\mathbf{P 4 8 3}$ & $\mathbf{P 7 6 4}$ & $\mathbf{P 7 6 5}$ & $\mathbf{P 7 6 6}$ \\
D1 & 0 & 0 & 0 & 113 & 115 & 98 & 0 & 0 & 0 & 0 & 0 & 0 & \\
D2 & 101 & 59 & 67 & 64 & 208 & 253 & 59 & 81 & 93 & 0 & 57 & 0 & \\
D3 & 82 & 79 & 0 & 301 & 346 & 304 & 76 & 106 & 0 & 99 & 83 & 0 & \\
D4 & 187 & 0 & 0 & 0 & 0 & 0 & 66 & 0 & 0 & 0 & 0 & 0 & \\
D5 & 0 & 0 & 0 & 71 & 126 & 119 & 0 & 0 & 0 & 57 & 0 & 52 & \\
\hline
\end{tabular}


Molecular weight (bp)

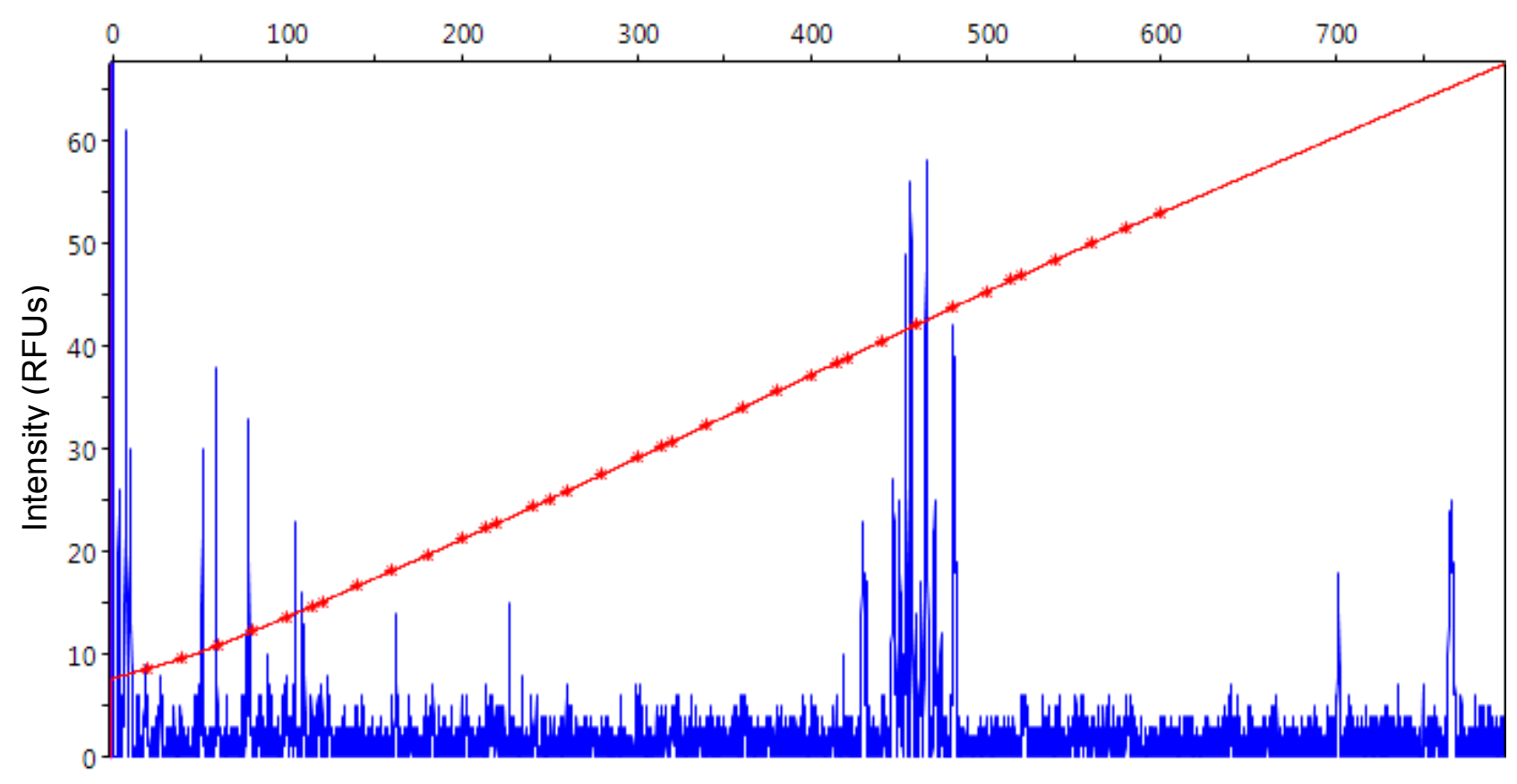

Figure 6a: Electropherogram of D1 from T2 using RsaI (sample 1)

The $\mathrm{x}$-axis represents fragment length which is a measurement of molecular weight in bp, which is a direct measure of a given phylotype frequency, and this bp number is the phylotypes ID. The y-axis is the peak height measured in Relative Fluorescent Units (RFUs) or intensity. The diagonal line is the sizing curve; each size standard peak correlates to a data point along this line. 


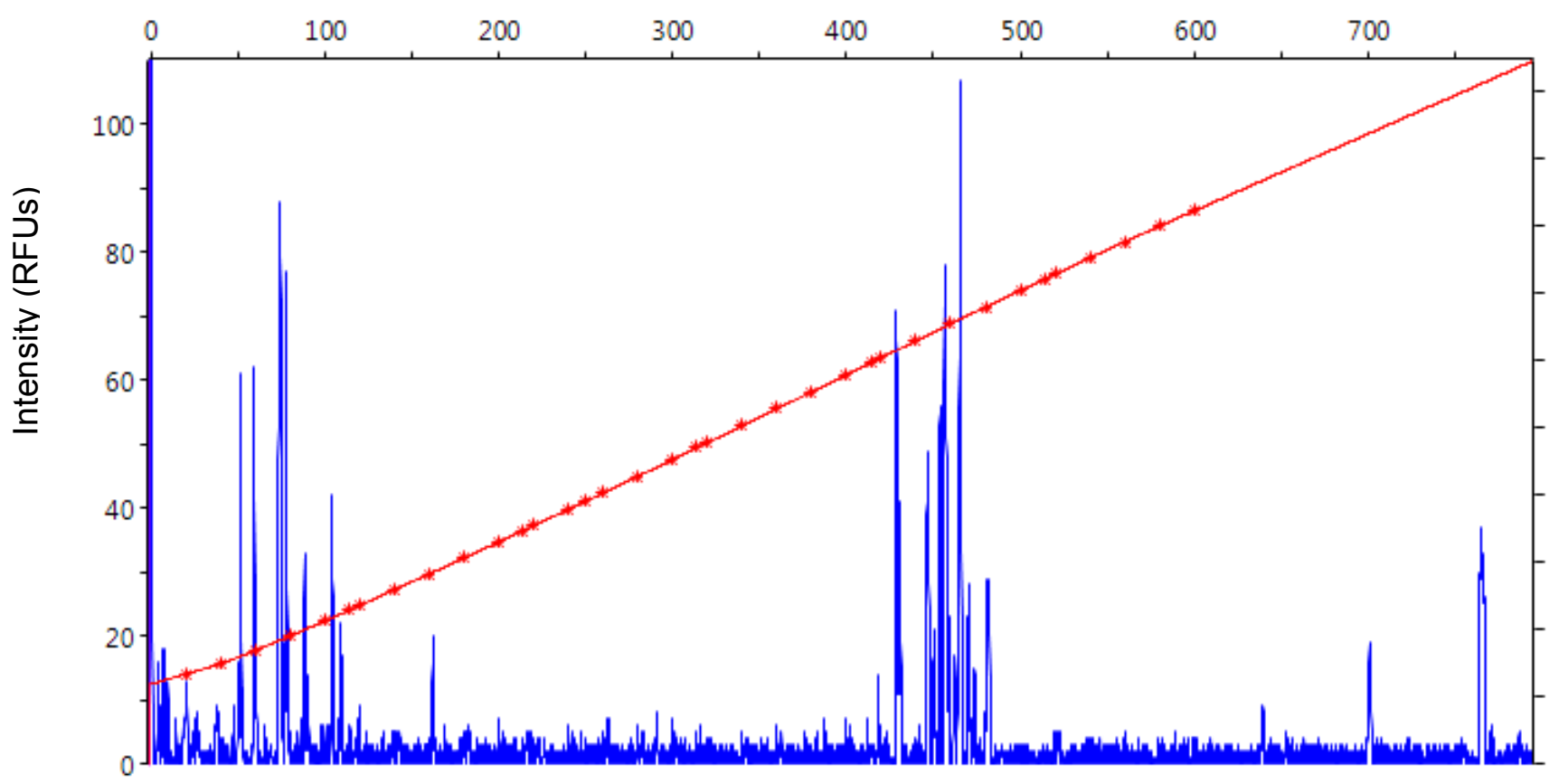

Figure 6b: Electropherogram of D1 from T2 using RsaI (sample 2)

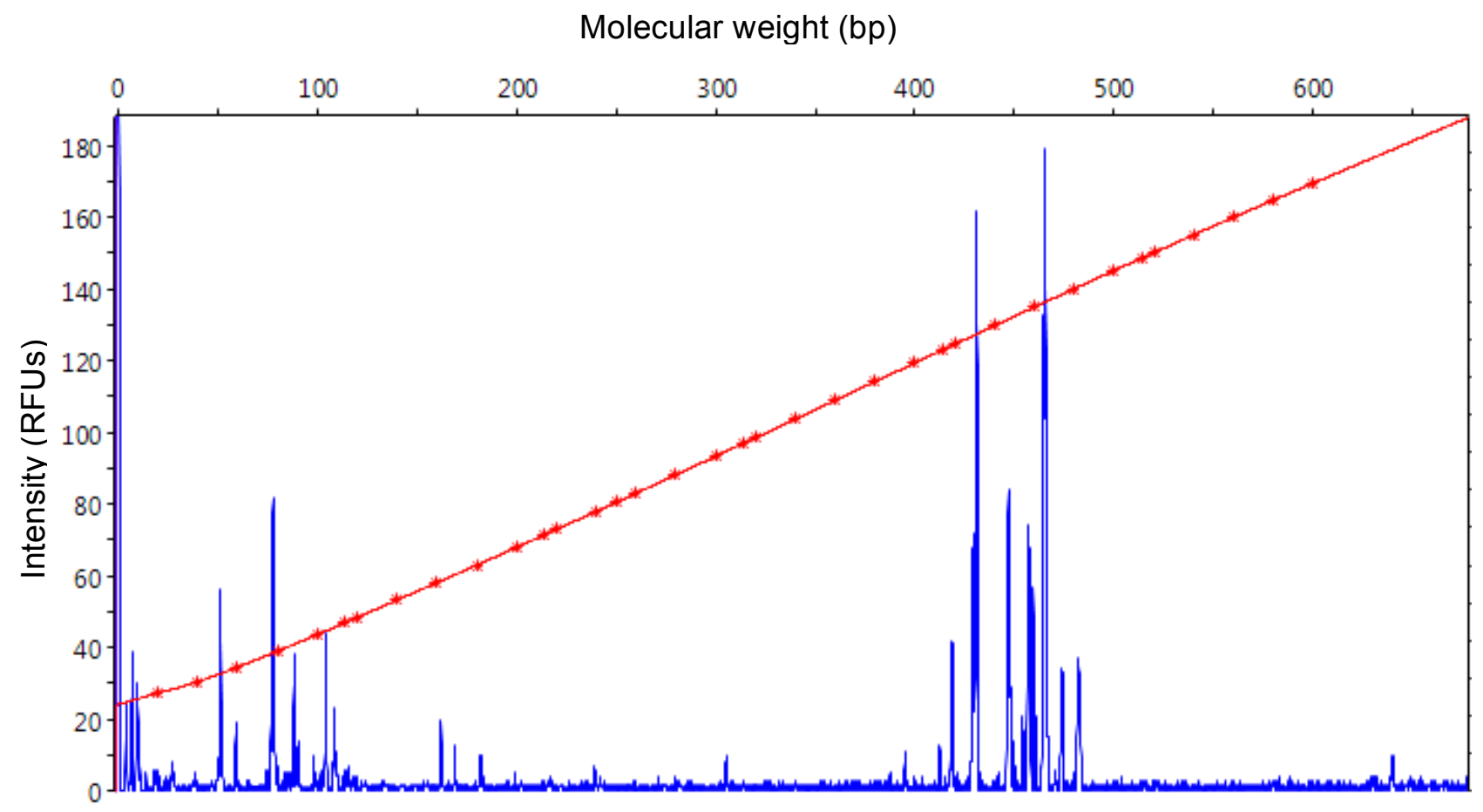

Figure 6c: Electropherogram of D1 from T9 using RsaI (sample 1) 


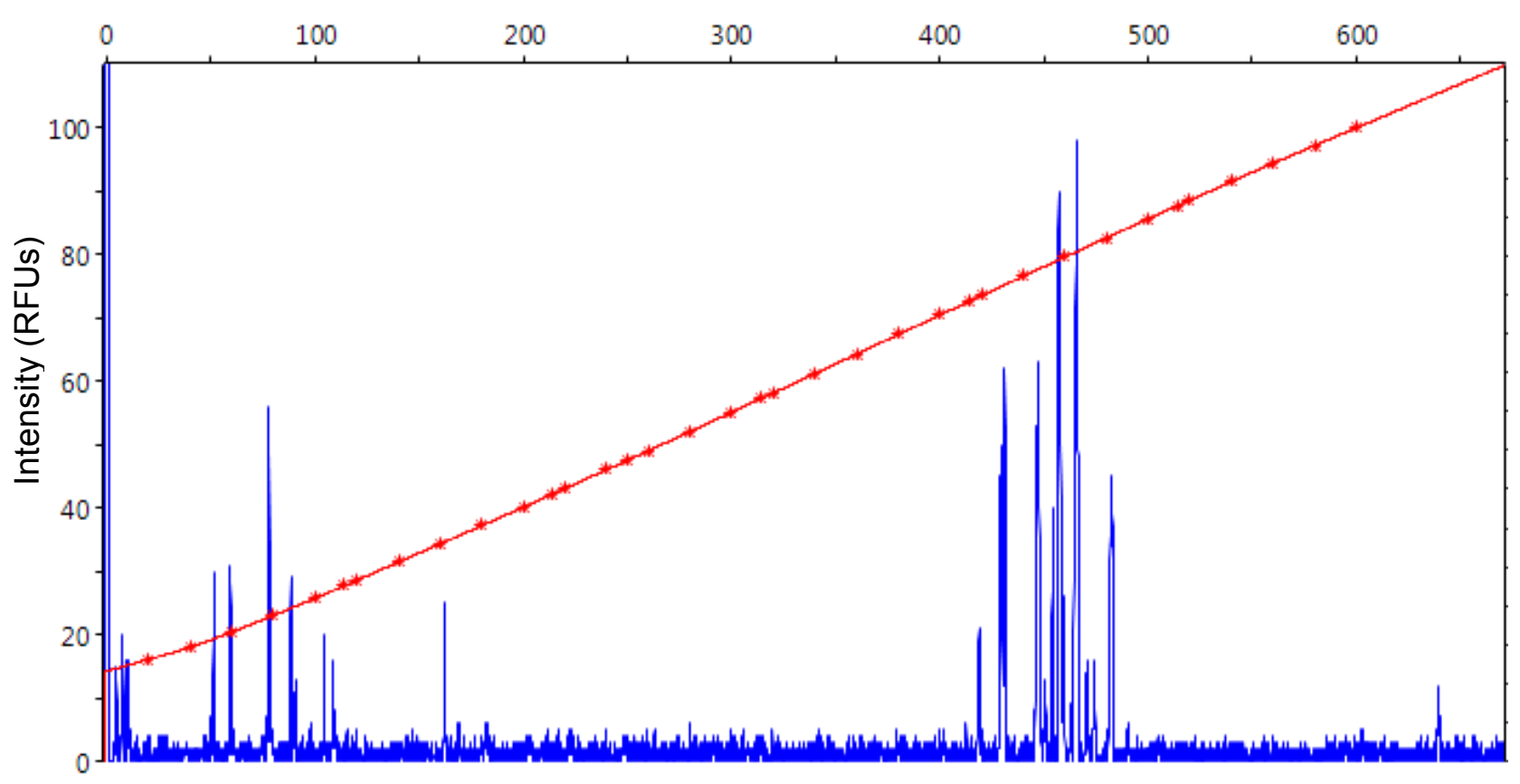

Figure 6d: Electropherogram of D1 from T9 using RsaI (sample 2)

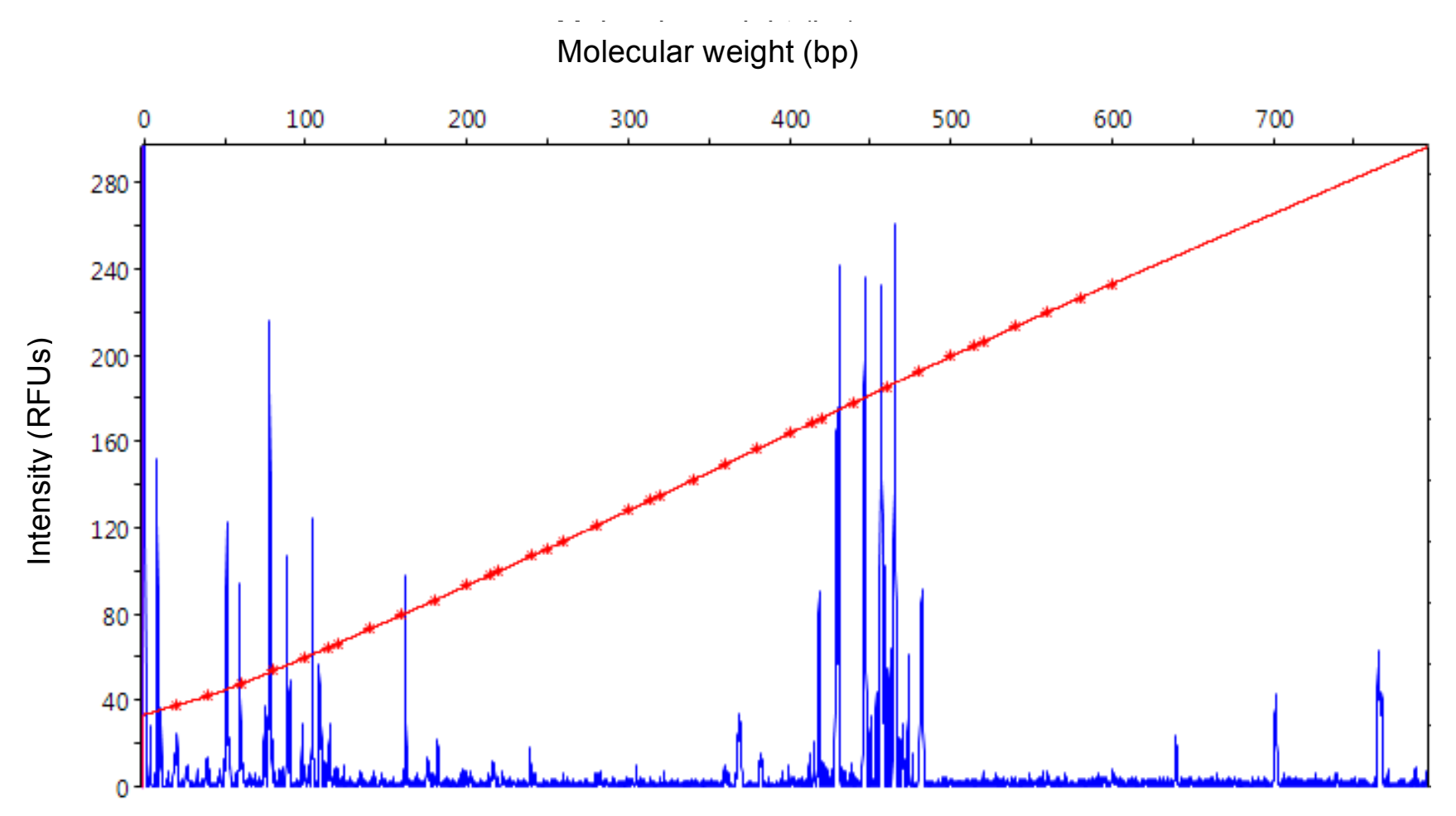

Figure 7a: Electropherogram of D2 from T2 using RsaI (sample 1) 


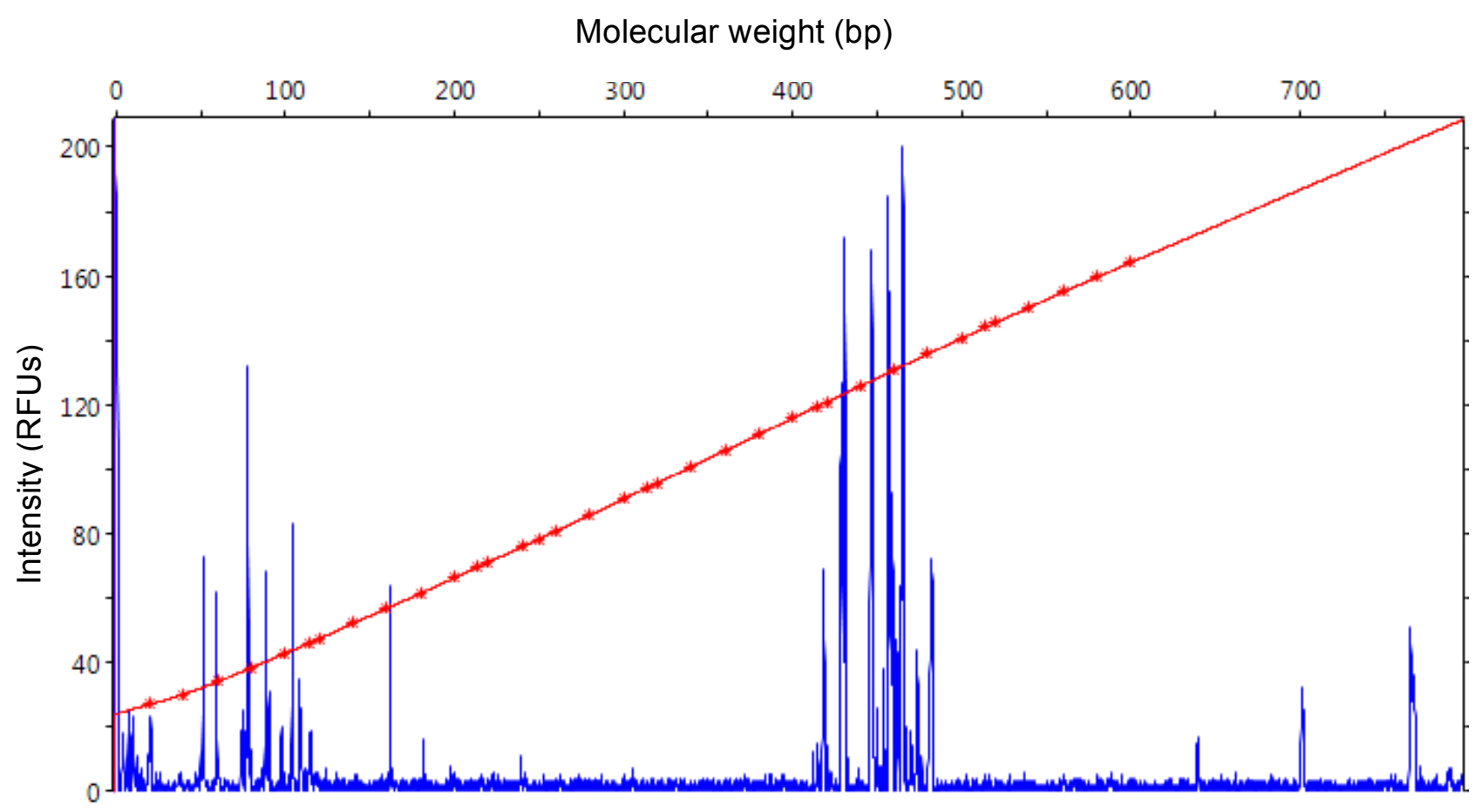

Figure 7b: Electropherogram of D2 from T2 using RsaI (sample 2)

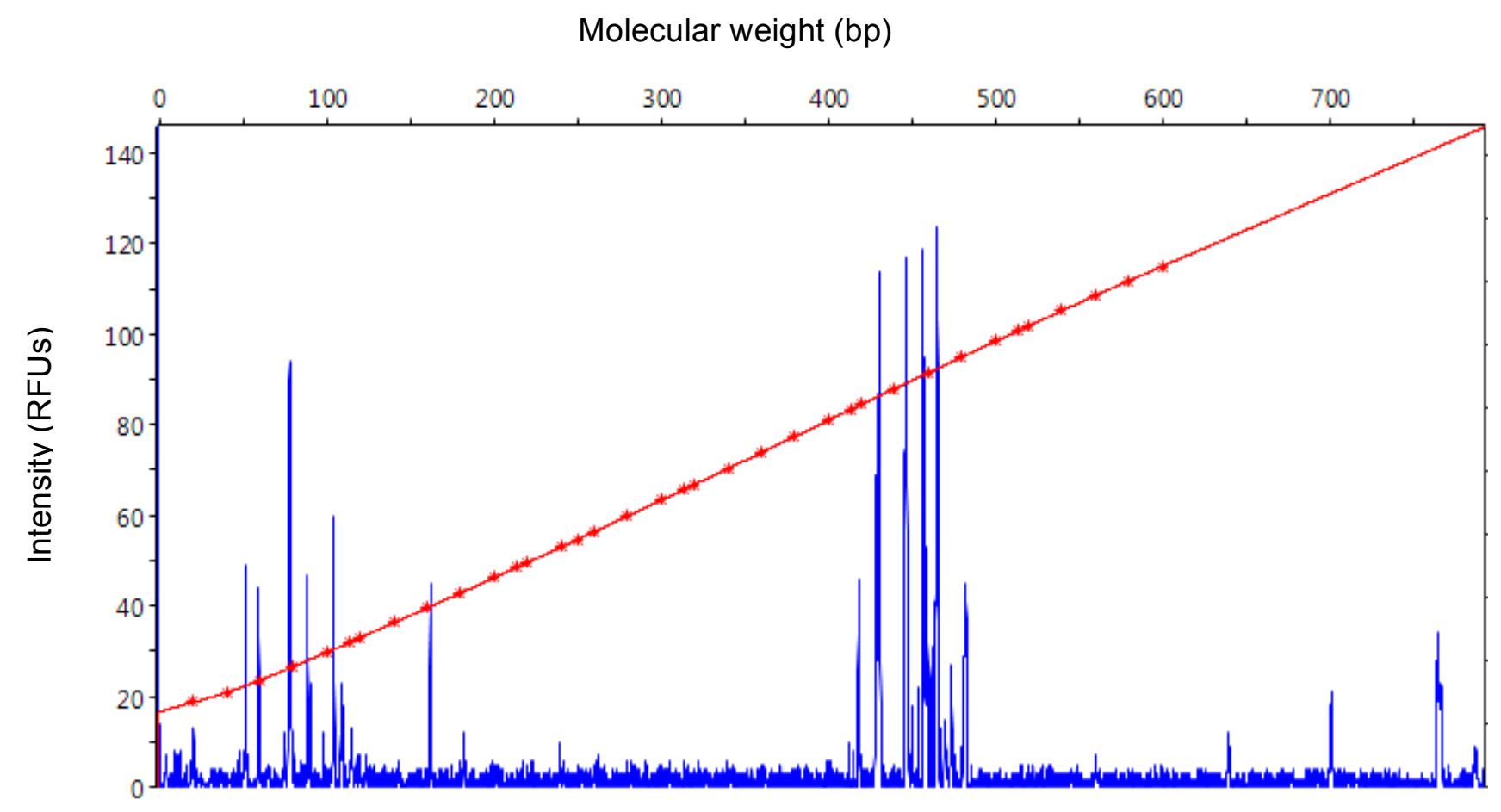

Figure 7c: Electropherogram of D2 from T5 using RsaI (sample 1) 


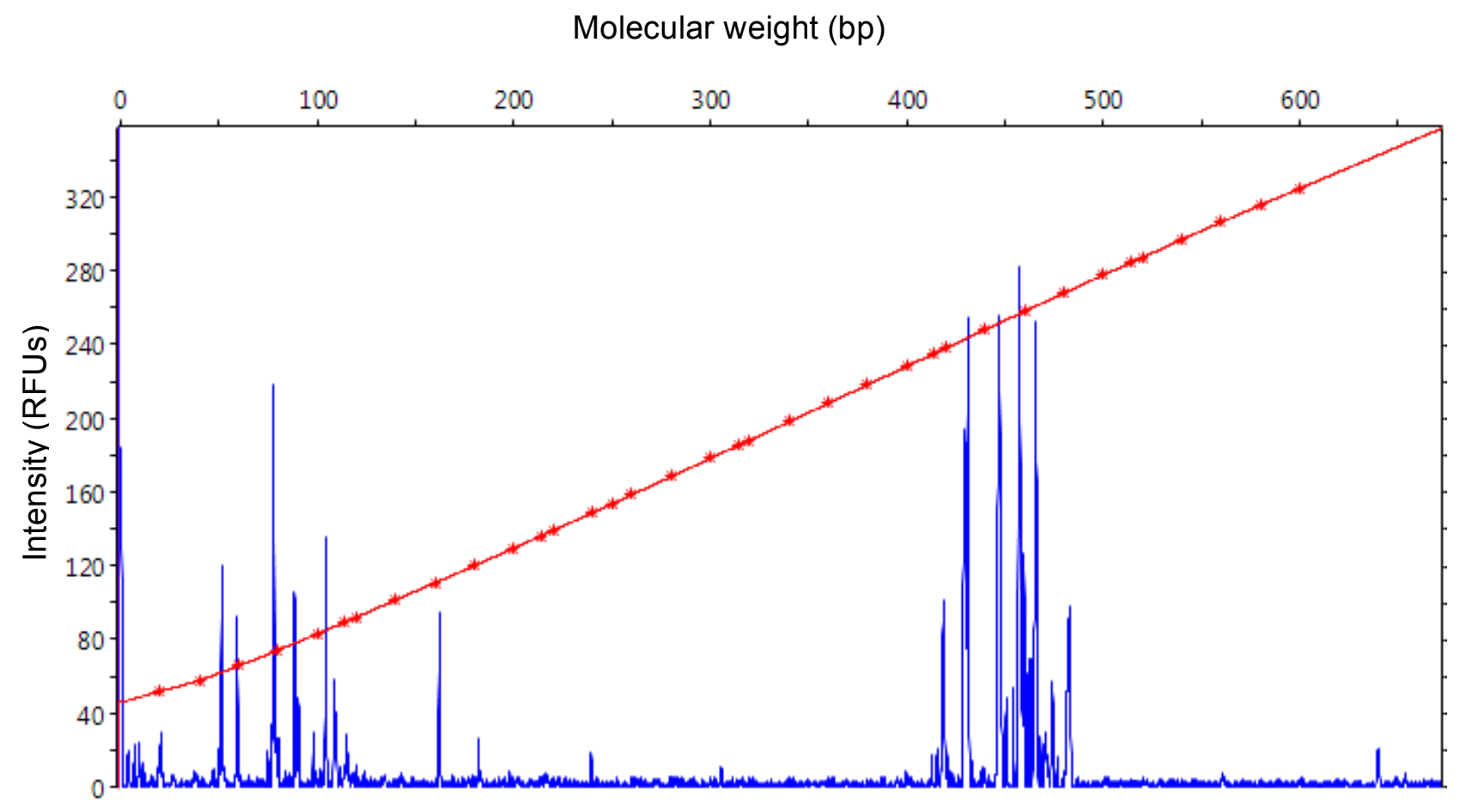

Figure 7d: Electropherogram of D2 from T5 using RsaI (sample 2)

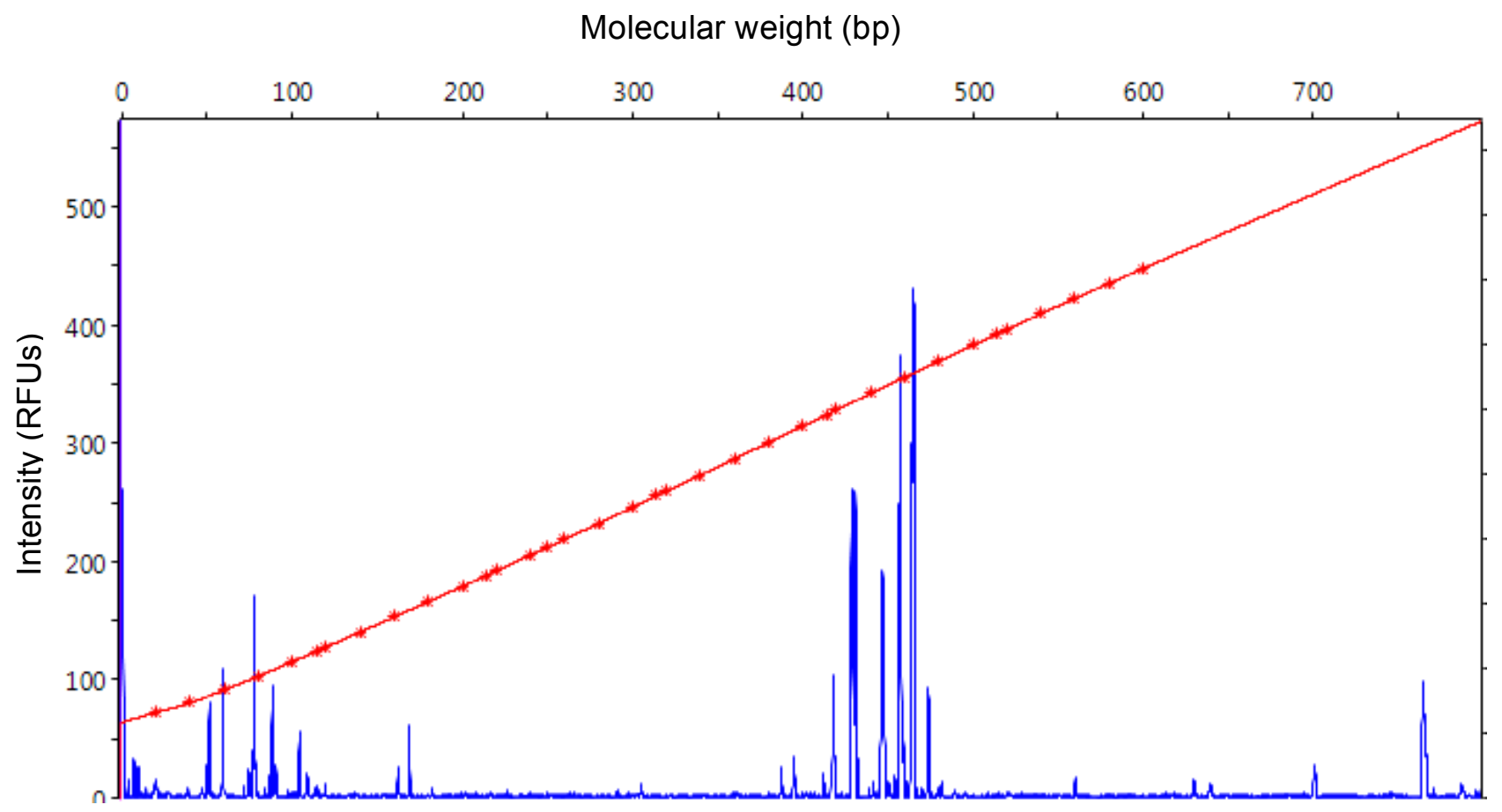

Figure 8a: Electropherogram of D3 from T1 using RsaI (sample 1) 


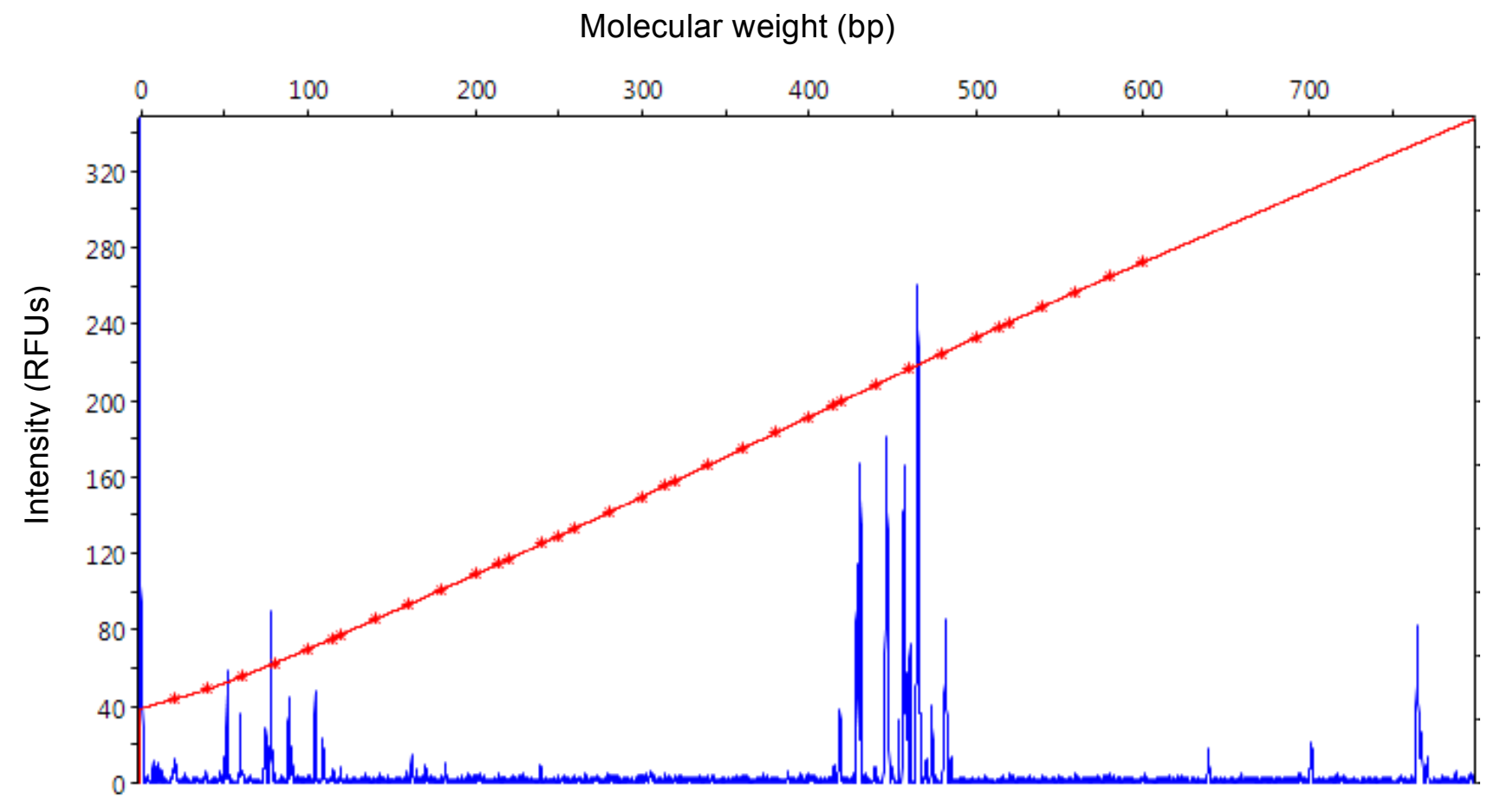

Figure 8b: Electropherogram of D3 from T5 using RsaI (sample 1)

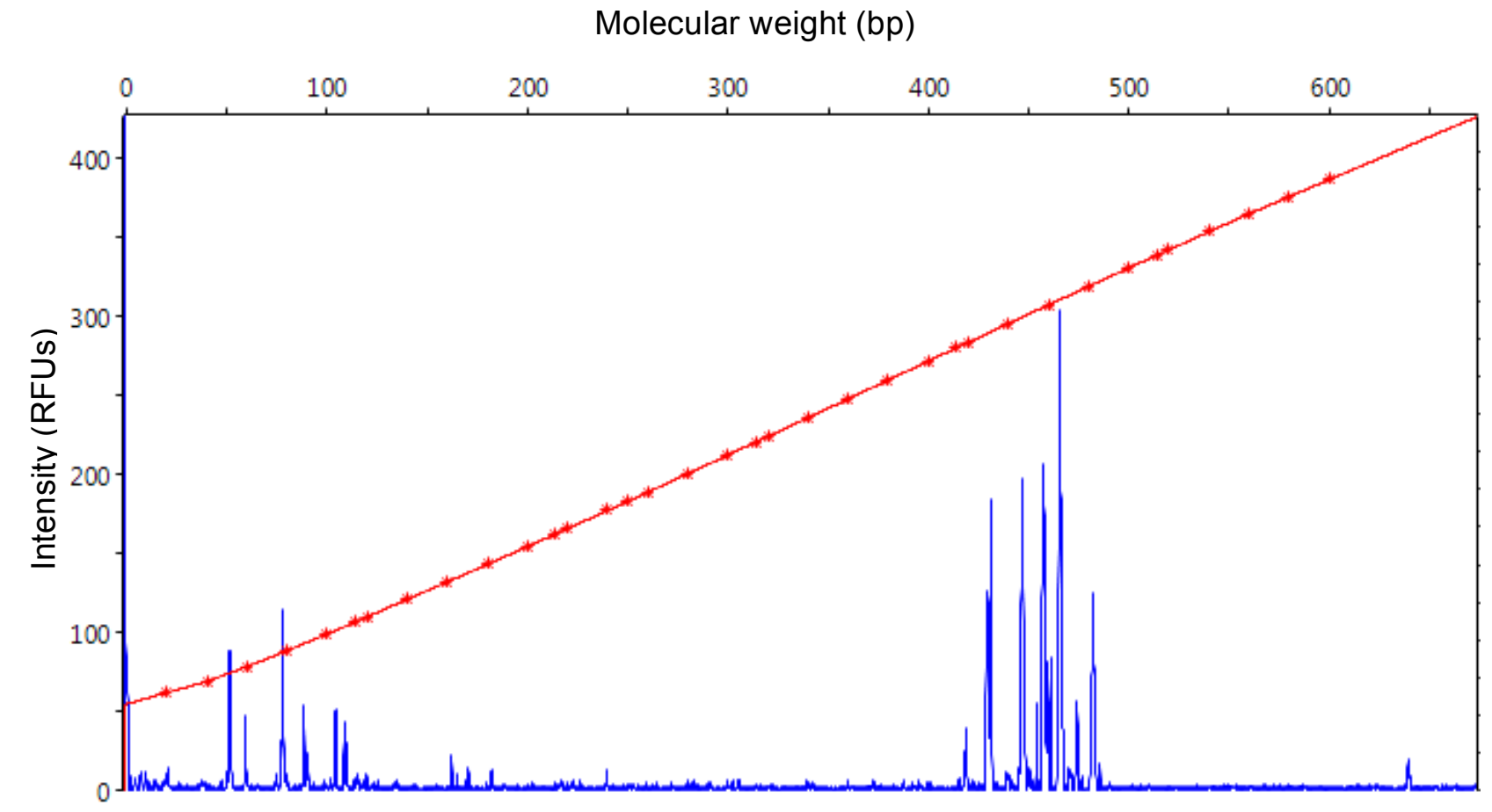

Figure 8c: Electropherogram of D3 from T5 using RsaI (sample 2) 


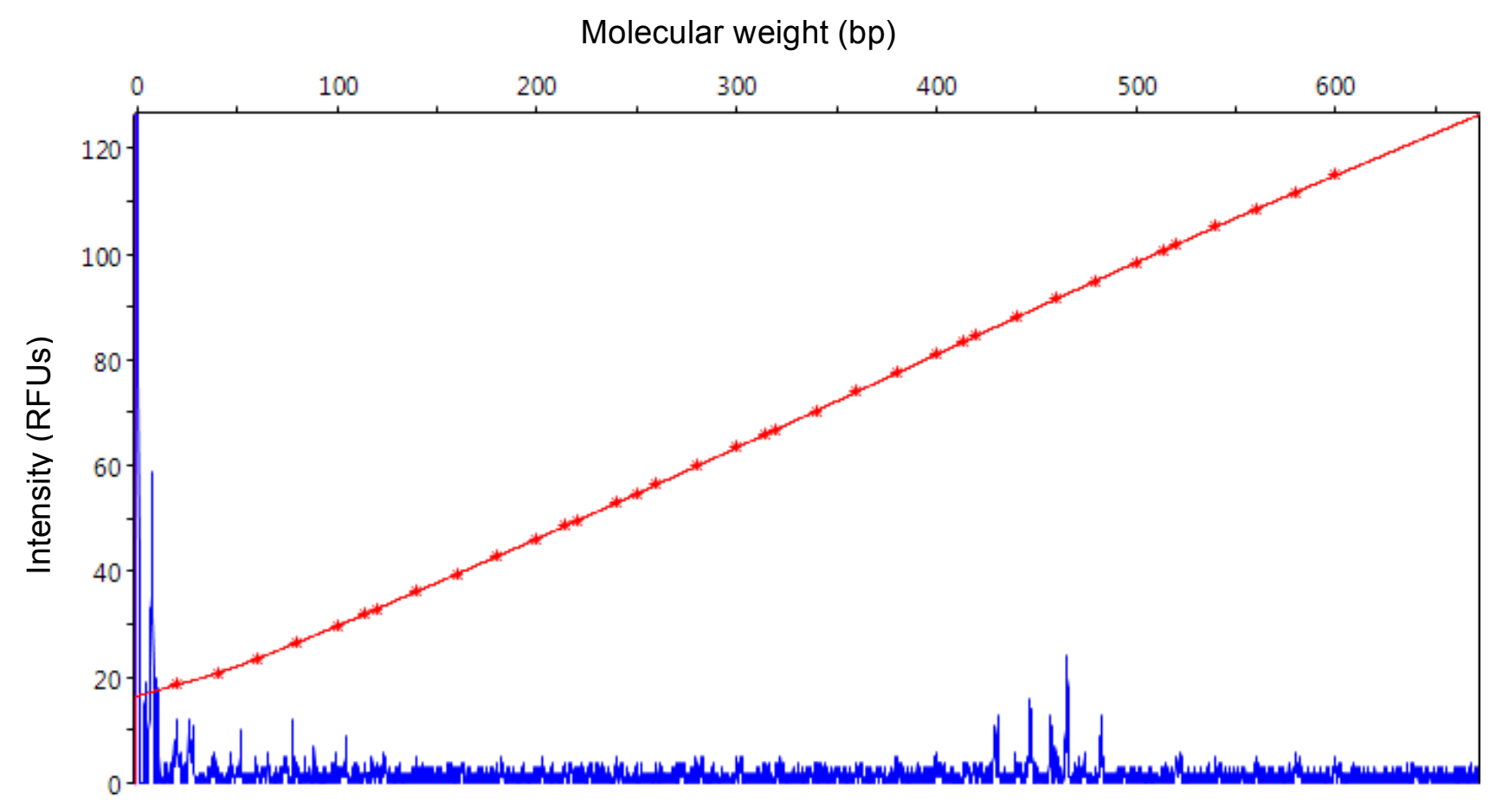

Figure 8d: Electropherogram of D3 from T9 using RsaI (sample 2)

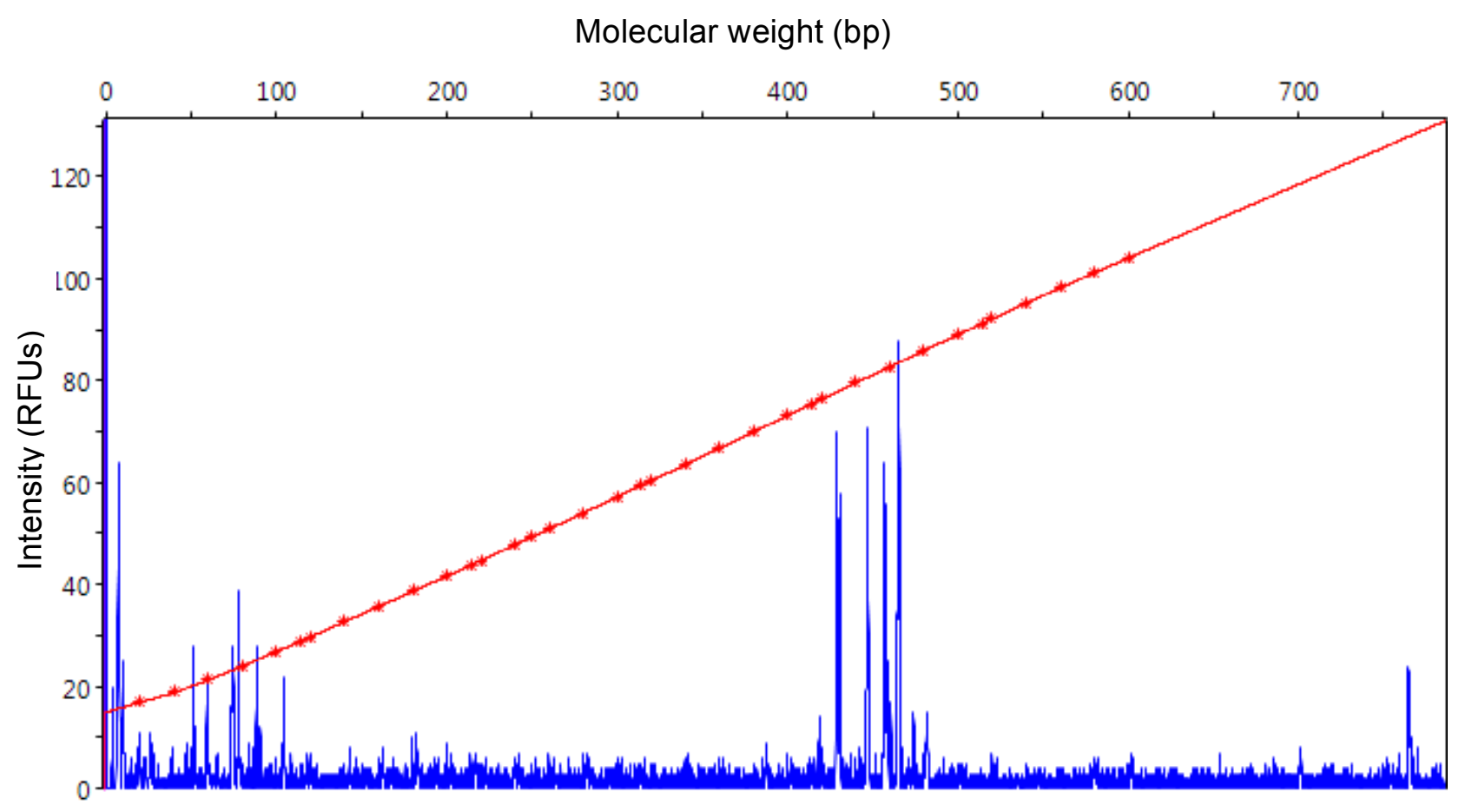

Figure 9a: Electropherogram of D4 from T2 using RsaI (sample 2) 


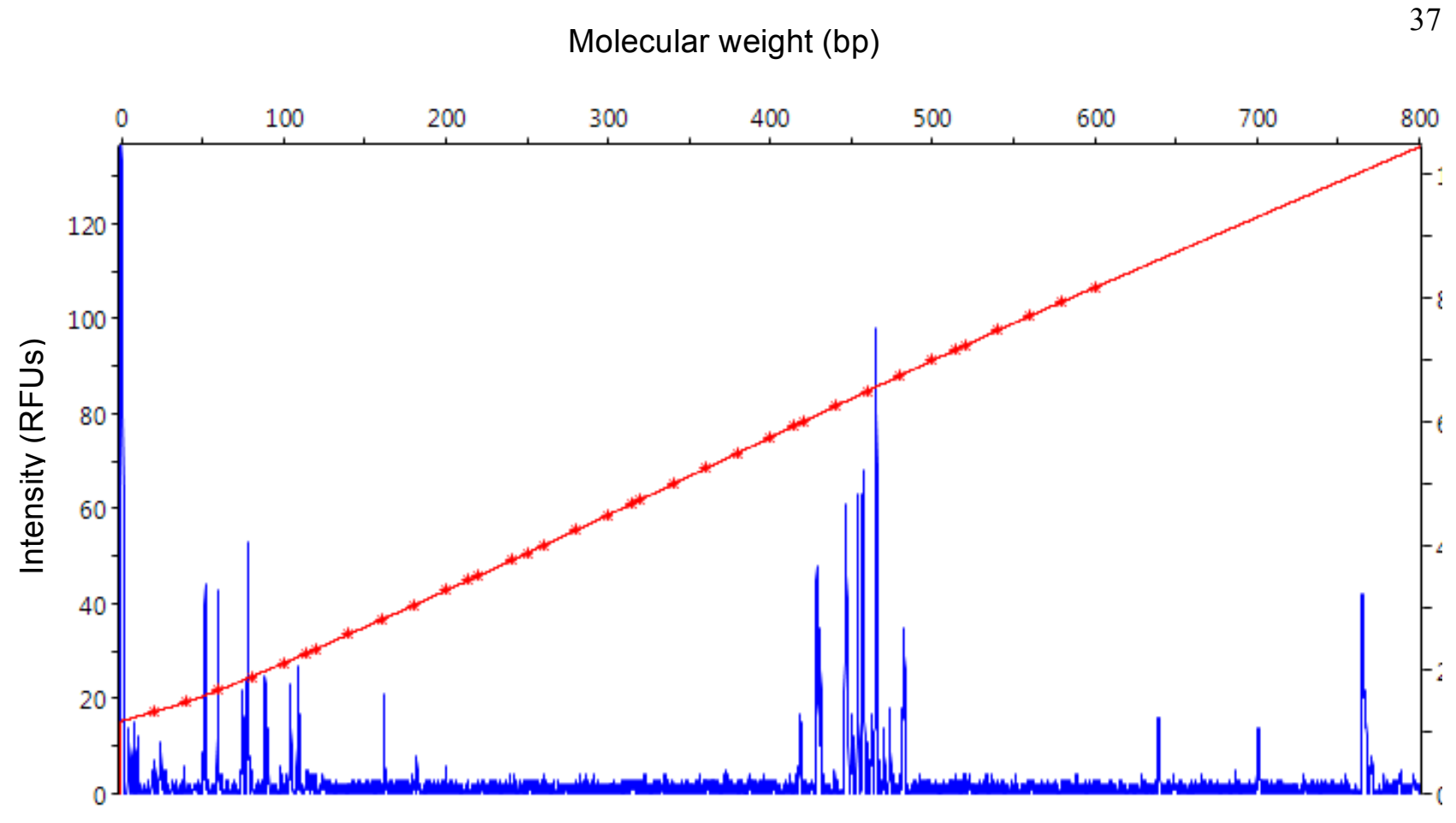

Figure 9b: Electropherogram of D4 from T5 using RsaI (sample 1)

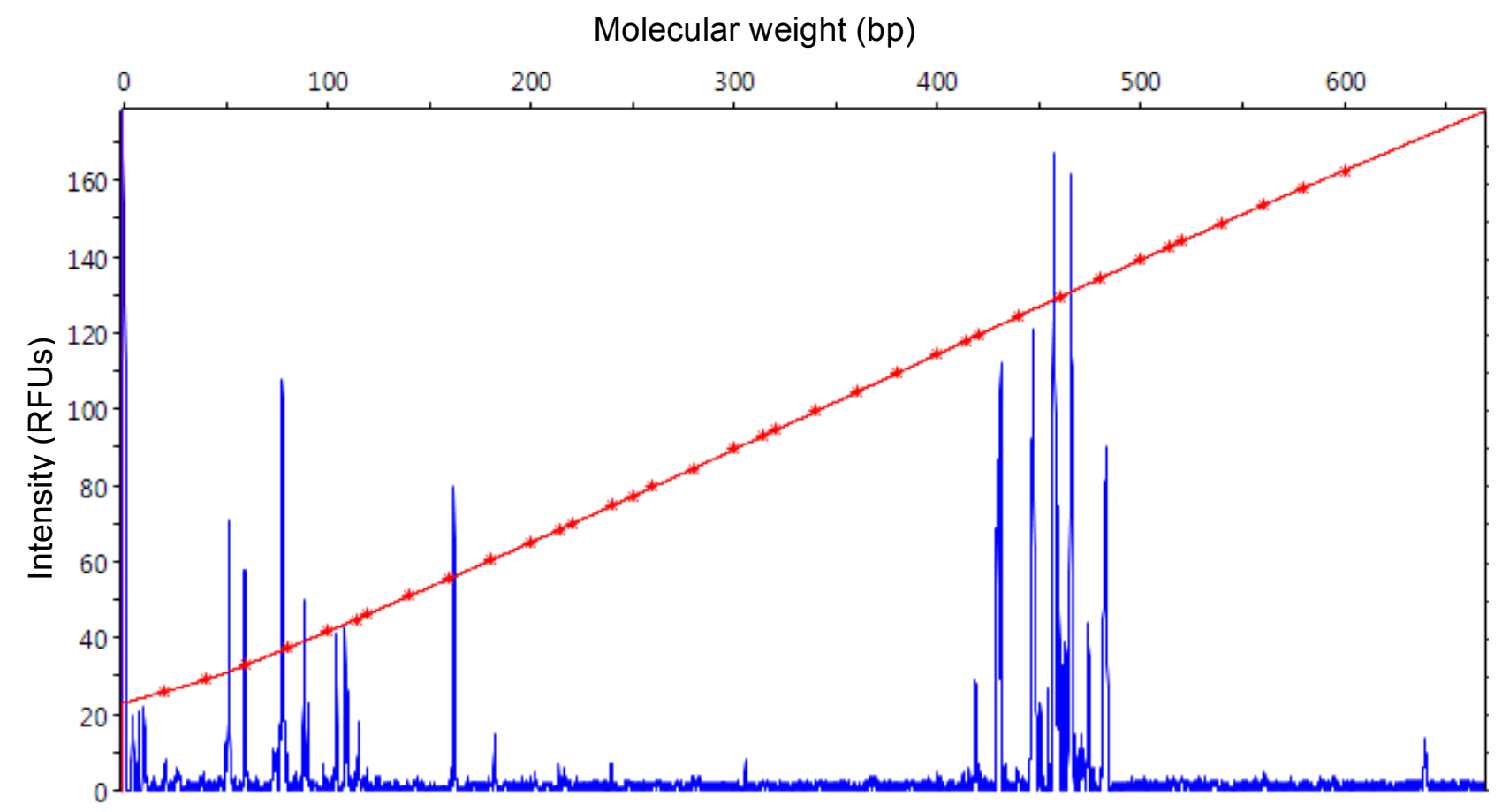

Figure 9c: Electropherogram of D4 from T5 using RsaI (sample 2) 
Molecular weight (bp)

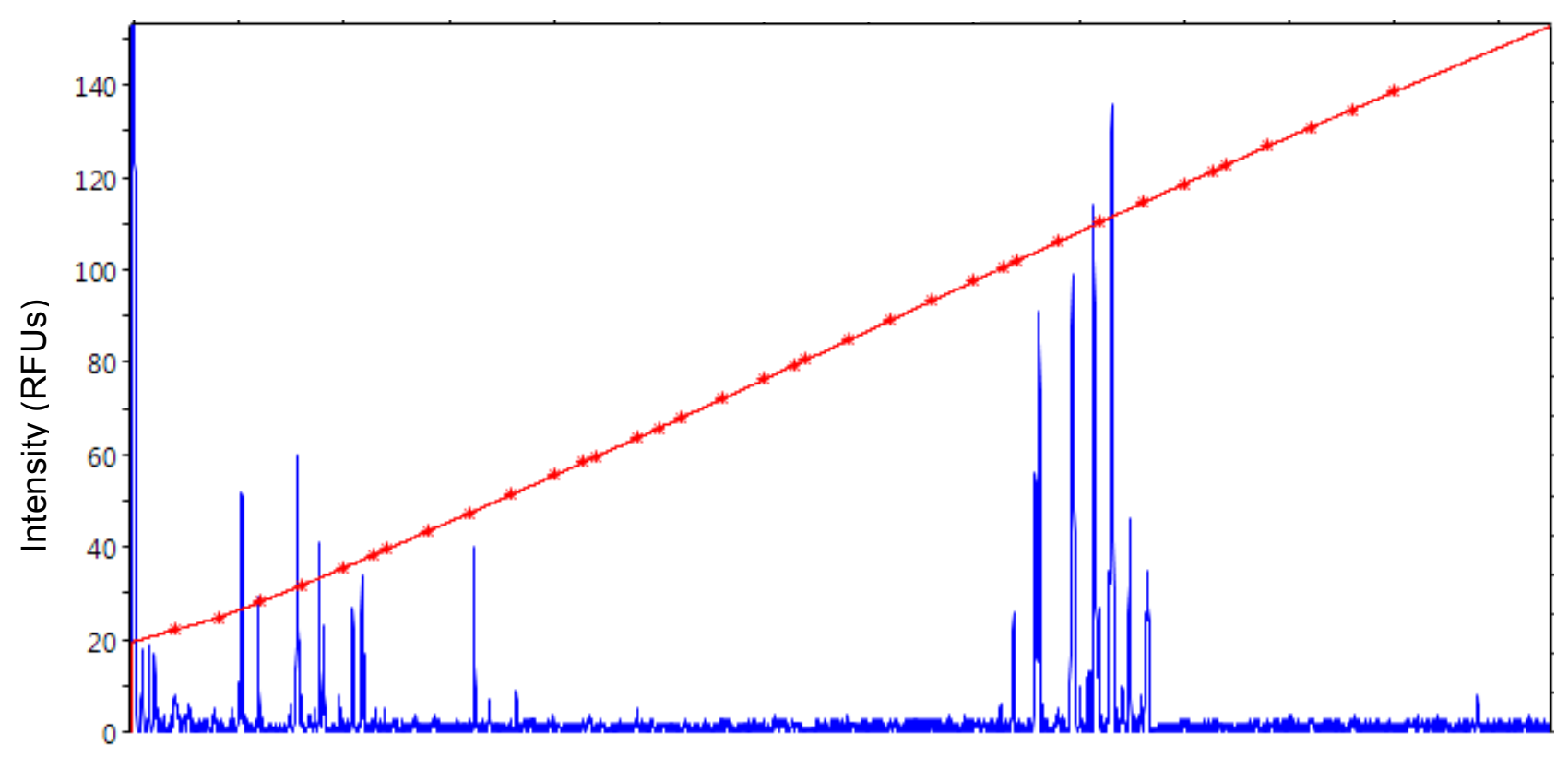

Figure 9d: Electropherogram of D4 from T9 using RsaI (sample 2)

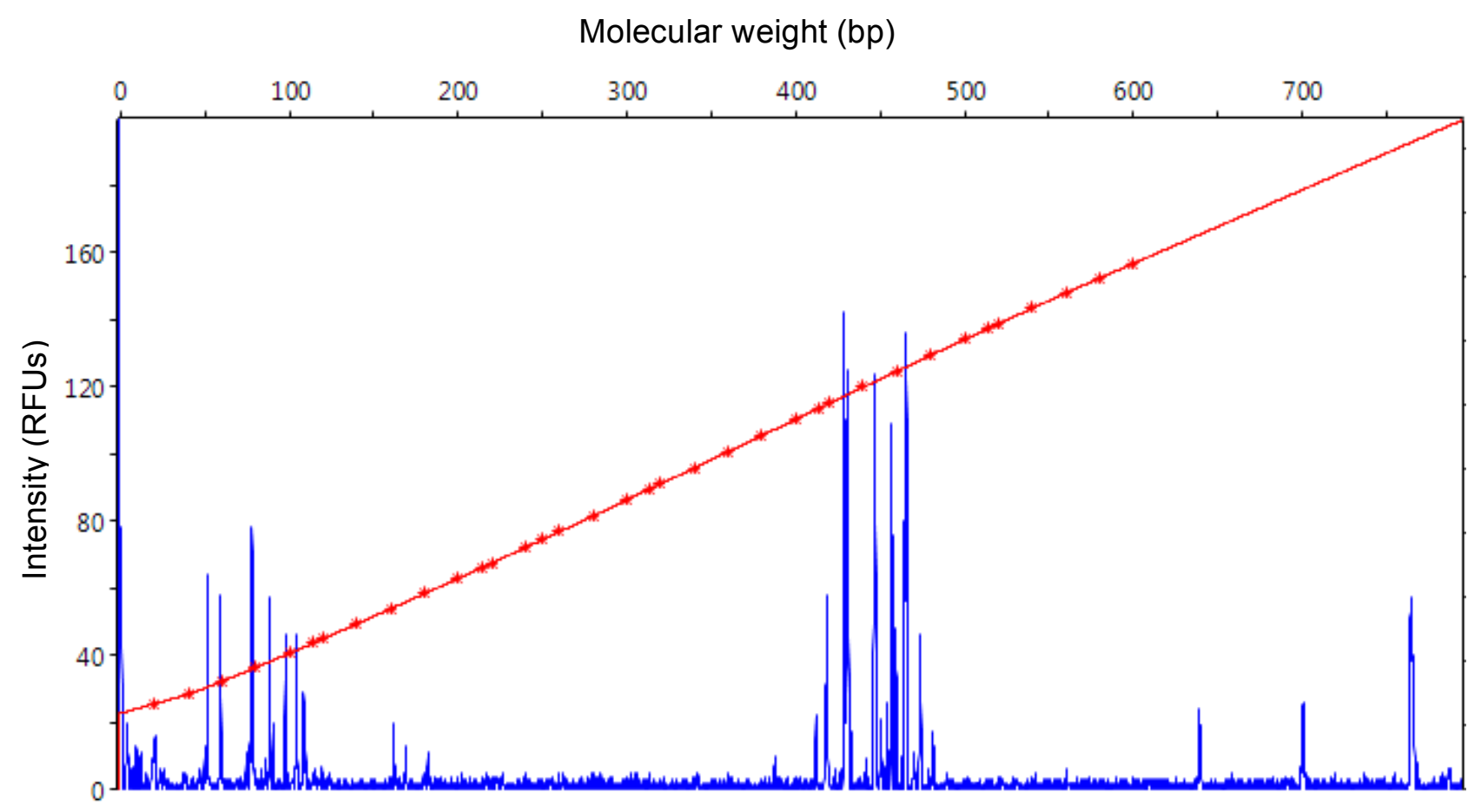

Figure 10a: Electropherogram of D5 from T2 using RsaI (sample 1) 


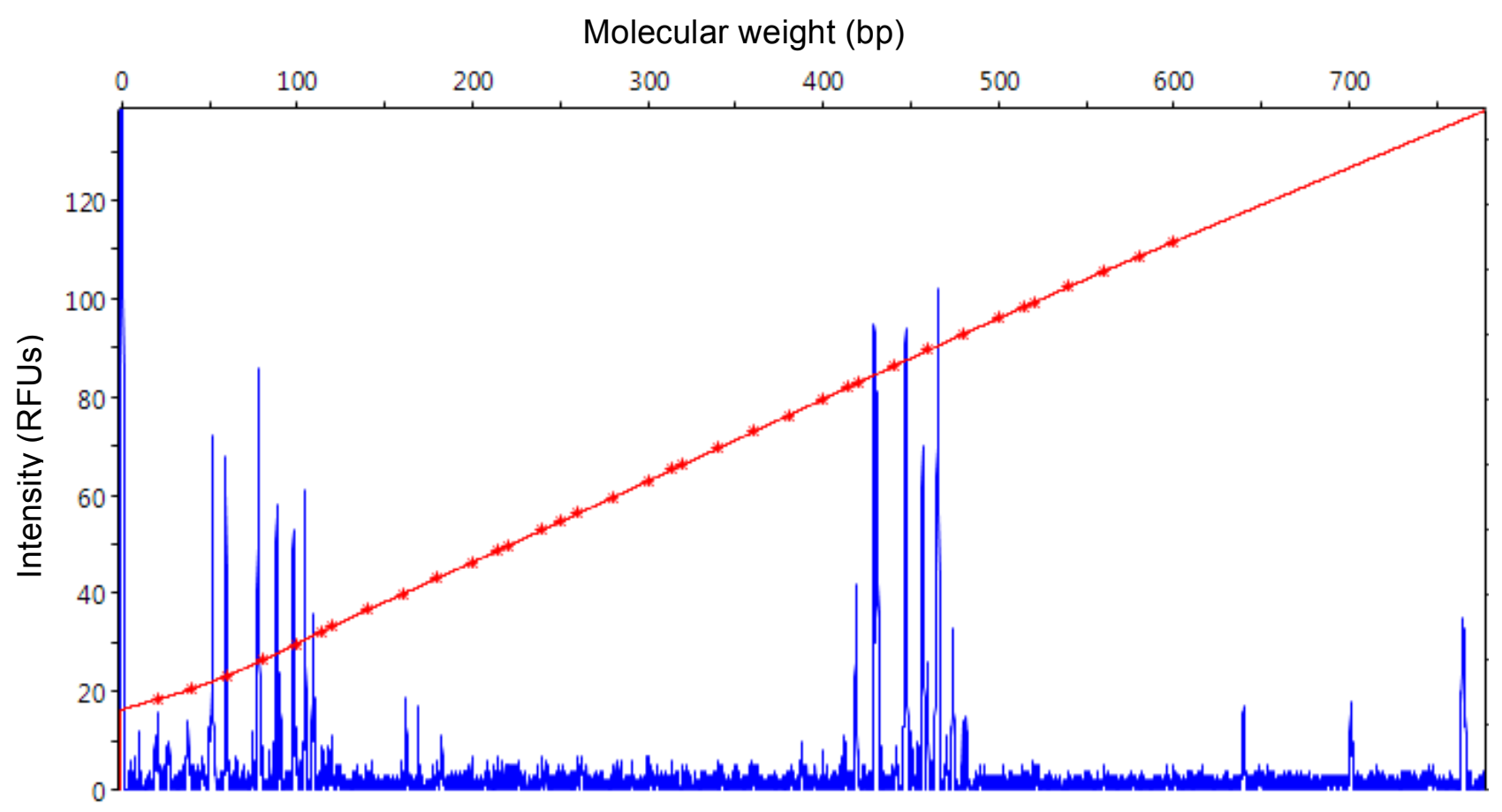

Figure 10b: Electropherogram of D5 from T2 using RsaI (sample 2)

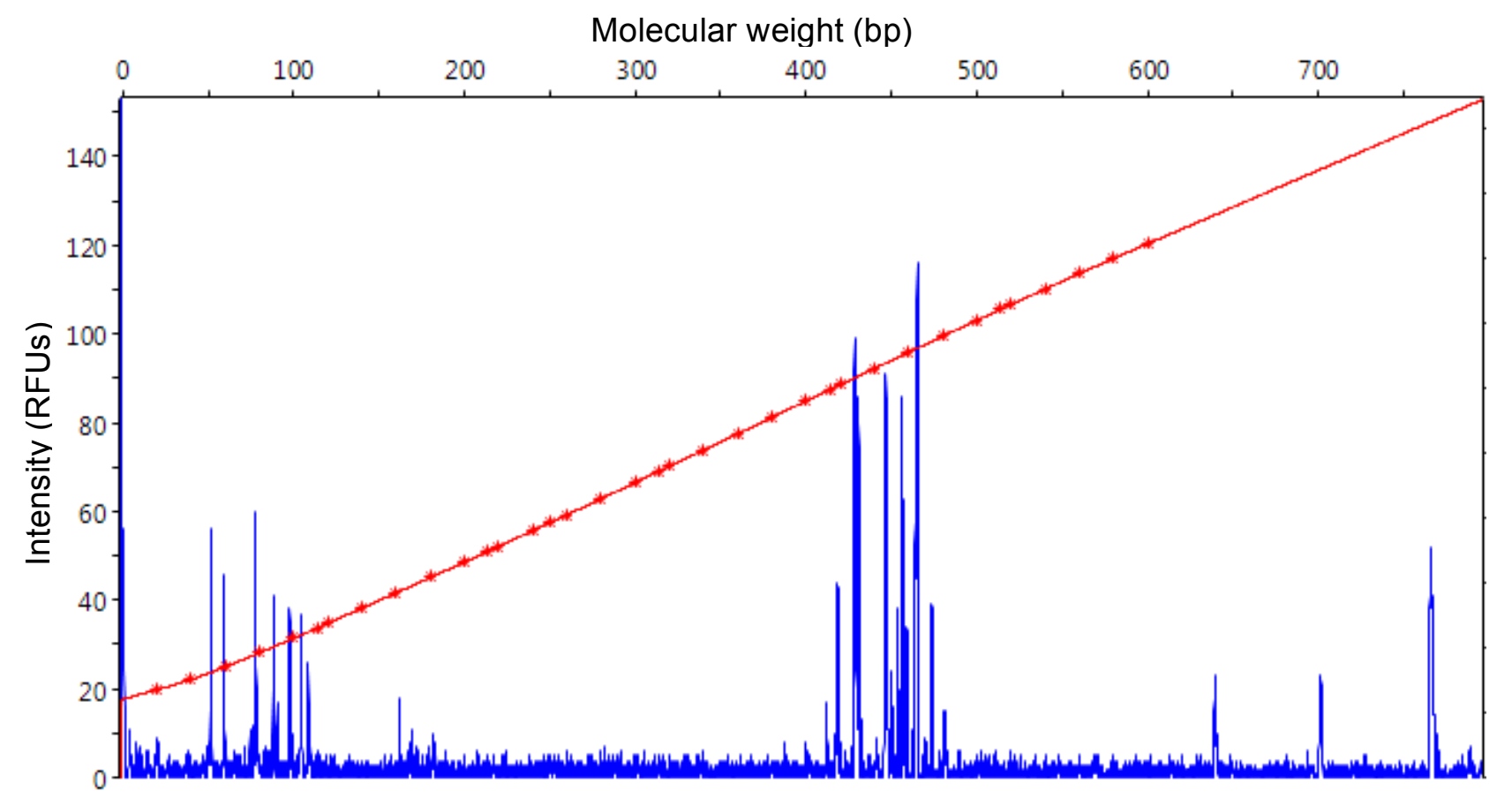

Figure 10c: Electropherogram of D5 from T5 using RsaI (sample 1) 
Molecular weight (bp)

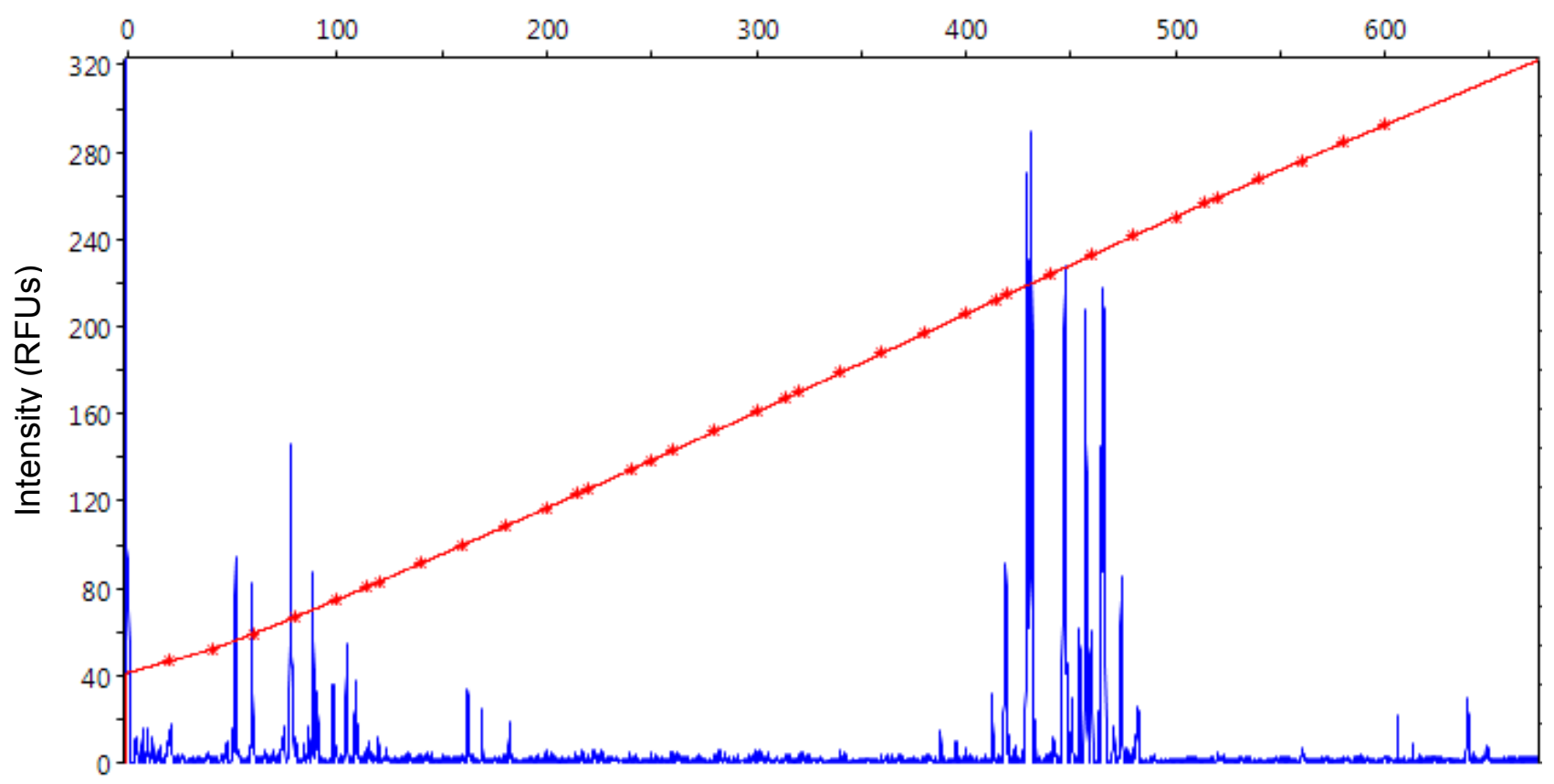

Figure 10d: Electropherogram of D5 from T5 using RsaI (sample 2)

The richest bacterial community (29 phylotypes) was at the edge (D2); D3, $10 \mathrm{~m}$ away from the edge, yielded the next richest community (24 phylotypes); D4 and D5 both had 19 phylotypes, and the gap (D1) had the lowest phylotype richness (16 phylotypes) (Figure 11). However, none of these differences were statistically significant $\left(\chi^{2}\right.$ goodness-of-fit test $\left.p>.05\right)$. 


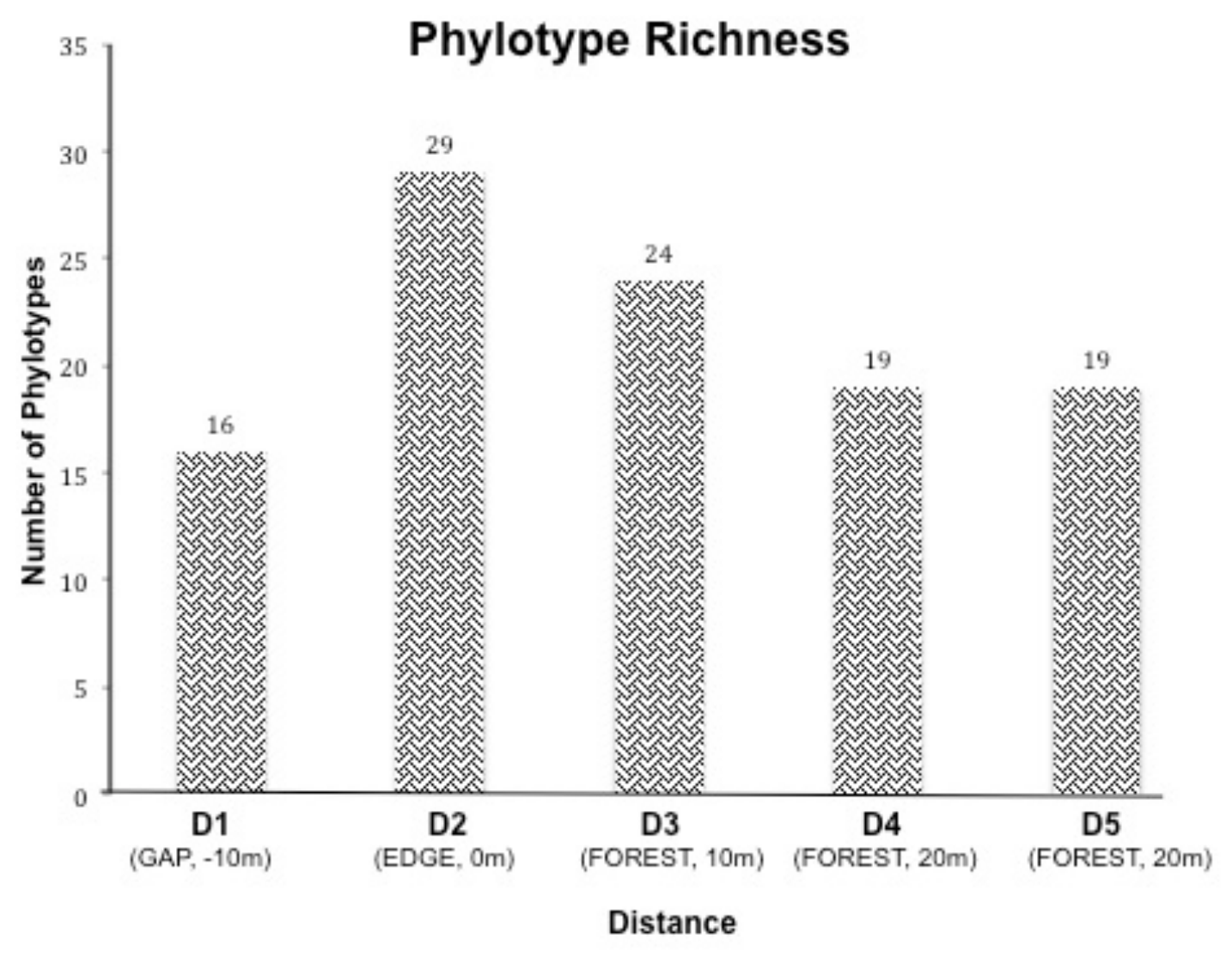

Figure 11 Phylotype richness at each distance along experimental transects $\cdot \chi^{2}=4.13<\mathrm{c} . \mathrm{v}=$ 5.991 with $2 \mathrm{df}$; therefore no significant difference among distances.

Simpson's Diversity Index (D) for phylotype diversity was significantly different when I removed D5 from the $\chi^{2}$ goodness-of-fit analysis. My rational for removing D5 from the analysis is that there is a dirt road next to D5 that may cause edge effects in D5. The main edge (D2) had the highest diversity (37 phylotypes). The gap (D1) contained 22 phylotypes, D3 and D4 had 21 phylotypes, and D5 had 29 phylotypes (Figure 12). 


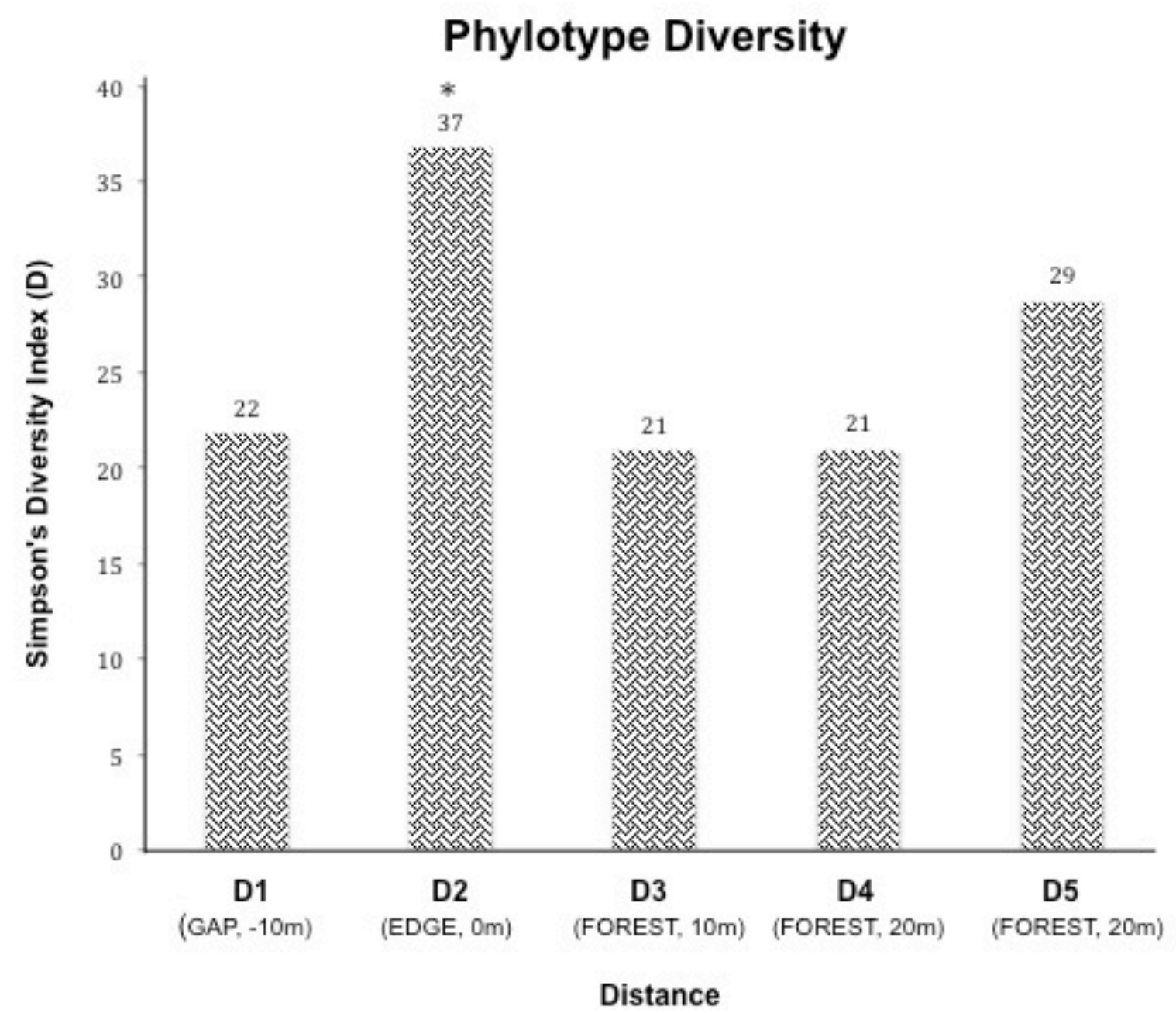

Figure 12: Simpson's Diversity Index for each phylotype community at each distance. $\chi^{2}=6.02$ $>\mathrm{cv}=5.991$ with $2 \mathrm{df}$; therefore there is a significant difference among D1-D4.

* D2 is different from all others.

In the combined CCA ordination of phylotypes and environmental variables (Figure 13) axis 1 is correlated with gravimetric water moisture, and axis 2 represents $\mathrm{pH}$ and temperature (positive correlation with $\mathrm{pH}$, negative correlation with temperature). This ordination shows the spatial relationship among sampling distances. The gap (D1) it towards the top right, and the forested areas (D3-D5) are on the left side and towards the bottom of the ordination. The edge (D2) is at the center of the ordination suggesting that it represents an ecotone between the gap and forest, 
and the greatest number of phylotypes surrounds it. Figure 14 is a cluster dendrogram that shows that the gap (D1) is most dissimilar of all the sampling distances. D2 and D3 are similar, and D5 is closely related to them.

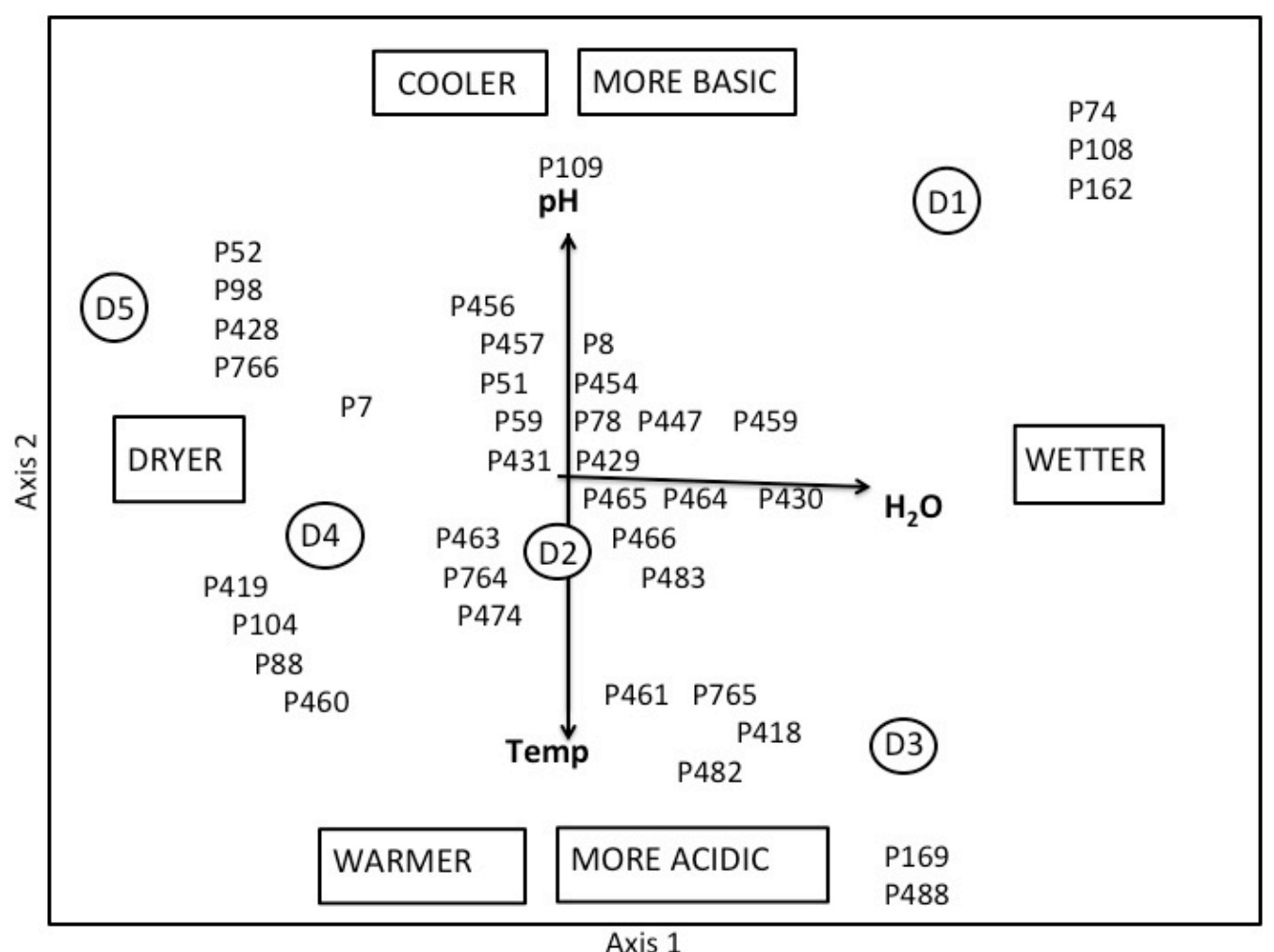

Figure 13: Joint CCA of phylotype matrix and environmental matrix. Phylotype number equals the TRFLP DNA fragments molecular weight. $\mathrm{pH}$ gradient increases from bottom to top of ordination; temperature gradient goes from cooler at the top of the ordination to warmer at the bottom. The soil water moisture gradient goes from dryer on the left side to wetter on the right side of the ordination. 


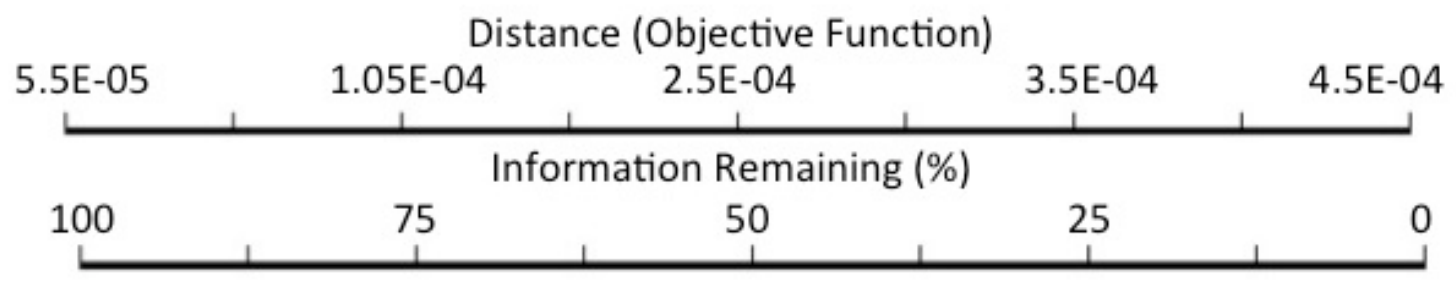

D1

D2

D3

D5

D4

Figure 14: Cluster Dendrogram showing relationship among sampling distances. The gap (D1) is the most dissimilar sampling distance.

Table 5 shows the ordination axis scores for the environmental variables measured at each

distance. The Monte Carlo tests of significance shows that there is no linear relationship between the phylotype structure and the environment structure. The null hypothesis can not be rejected because $p$ value $=.2993>.05($ Table 5$)$.

Table 5: Randomization test results - phylotype-environment correlations

Real data Monte Carlo test, 998 runs

\begin{tabular}{cccccc}
\hline Axis & \multicolumn{2}{c}{ Spp-Environ Corr } & Mean & Minimum & Maximum p \\
1 & 0.999 & 0.998 & 0.992 & 1.000 & 0.2993 \\
2 & 0.999 & 0.993 & 0.977 & 1.000 & \\
3 & 0.982 & 0.984 & 0.968 & 0.996 & \\
\hline
\end{tabular}




\section{DISCUSSION}

\section{Environmental Variables \& Phylotype Richness and Diversity}

The phylotype diversity results support my hypothesis that the edge (D2) (with 37 phylotypes) would contain the most diverse community. The gap contained 22 phylotypes, while both D3 and D4 had 21 phylotypes. D5, the furthest distance from the gap, was the second most diverse with 29 phylotypes. This was surprising because I hypothesized that diversity would decrease as distance from the gap increased, but a dirt road is at the end of D5 perhaps acting as a small gap, and thus making D5 somewhat of an edge. Edge effects can be seen in both D2 and D5, and the cluster dendrogram (Figure 13) shows that D2 and D5 are indeed very simialr in phylotpye compostion. Phylotype richness was highest at the edge, but lowest in the gap, similar to what Bauhus (1996) found when he measured microbial biomass along a gap-stand gradient in a European beech (Fagus sylvatica) forest. Phylotype richness at D3 was the second highest (with 24 phylotypes) similar to the edge effect the RIC Forest Ecology Lab found in a separate study where canopy trees increased their radial growth up to $10 \mathrm{~m}$ from the edge which is where D3 is located, and Mascarúa-López et al., (2006) found the distance of the edge effect on forest structure extended 10-30 $\mathrm{m}$ from the edge in black spruce forests.

This study showed that soil bacterial diversity is influenced by forest gaps in a southern New England forest, and that soil environmental variables (soil temperature, soil moisture, and soil $\mathrm{pH}$ ) are different in the gap compared to the forest (although not significantly so). Greater temperature and soil moisture would support a higher rate of microbial mediated processes (organic matter decomposition and nitrogen mineralization for instance) and thus faster microbial reproduction rates. The creation of a gap removes all the aboveground plants and trees, 
thus stopping the removal of water from the soil through their roots, causing the gap to be wetter than the surrounding forest. The $\mathrm{pH}$ in the gap was slightly higher but not significantly so. Early spring soil temperature was lower in the gap (but not significantly so), which is similar to what other gap studies found. For example, Scharenbroch and Bockheim (2007) saw an increase in soil moisture and solar radiation in gaps throughout the entire year, and soil temperature was greater in gaps in the growing season only (May - October in southern New England). Their study was conducted in 6-9 year old gaps in a closed northern hardwood-hemlock forest (Midwestern USA). They also found that the edge was a nutrient hot spot with significantly greater microbial biomass compared to the forest and gap. For instance, Harper et al. (2005) found an increase in the diversity of saplings, herbs, and shrubs at man-made forest edges, and found that abiotic and biotic gradients are strong at newly created edges and weaker at older edges. The increased amount of light reaching the understory soil and the immediate increase in nutrients released and accumulation from decaying vegetation due to the fewer plant roots present for nutrient uptake may explain Harper's results. Similarily, Fergnani et al. (2013) found that the ecotone between grasslands and forests in the southern Brazilian highlands showed a peak in ant species richness and Watkins et al. (2003), in a study of understory plants and their response to unpaved forest roads in a northern hardwood landscape in the Chequamegon National Forest, Wisconsin, found that ecotones contained more plant species (especially exotic species) than the core areas of neighboring ecosystems. Thomas et al., (2010) found that $\mathrm{pH}$ explained most of the variance in bacterial composition, and Fierer and Jackson (2006) concluded that soil $\mathrm{pH}$ was the best predictor of both soil bacterial diversity and richness with the highest levels of diversity and richness seen in neutral soils. Bacteria have an optimal $\mathrm{pH}$, and a $\mathrm{pH}$ range at which they are active. The $\mathrm{pH}$ range at the Yale Myers Forest was small (5.5 to 5.9) 
hence soil $\mathrm{pH}$ may not be the best predictor of bacterial richness/diversity for this study. Curiel Yuste et al. (2013) found that the diversity of bacterial communities was strongly affected by soil temperature and soil moisture. Soil temperature was lowest in the gap while soil moisture was highest in the gap at Yale Myers forest and the gap had low phylotype diversity and the lowest phylotype richness.

My results suggest that the gap edge at Yale Myers Forest is an ecotone between the gap and the forest, and that its bacterial community is made up of some phylotypes from the gap, some from the forest as well as some specialized phylotypes adapted to soil conditions at the edge itself (Fig. 15), which is similar to what Baker (2002) found in bird communities across a natural edge ecotone in Australia. He surveyed 86 species, 31 of which he categorized according to their densities at the ecotone (ecotone neutral, ecotone shy, or ecotone conspicuous); seventeen species were ecotone-neutral, three species were ecotone shy, and eleven species were ecotone conspicuous. In my study, phylotypes P51, P59, P78, P429, P431 and P447 were found at all 5 sampling distances, and phylotypes P454, P456, P457, P459, P464, P466, and P474 where found in the gap, the edge and at least one or more forest sampling distances. Phylotypes P463 and P483 were examples of ecotonal species, only found at the edge (D2) (Fig. 15)

Other researcher did not see the same increase in species diversity at gap edge ecotones. For example, Leslie et al. (2014) measured shifts in ground beetles among a forest-to-agriculture ecotone in Northeastern US farms and found the highest levels of beetle richness in the forest community, not at the edge. Kamayev (2012) studied spider species diversity in a bog-to-forest ecotone in Eastern Fennoscandia (the Scandinavian Peninsula, Finland, Karelia, and the Kola Peninsula) and found no edge effect with the greatest spider diversity in the forest. Dangerfield et al. (2003) studied invertebrate (beetle, ant, wasp, fly and springtail) diversity across a natural 
edge between a riparian habitat and a saltbush habitat in a semiarid region of New South Wales, Australia, and no changes in invertebrate diversity at the edge were detected. These results suggest that the edge influence may be species specific, site specific or perhaps ecosystem specific. Although this study suggests that bacterial diversity does increase in response to the creation of gap, this diversity may be the result of bacterial homogenization, meaning there could be an overall net loss of diversity, and this loss of genetic variation in bacteria across a fragmented forest could degrade ecosystem resilience and make it harder for the ecosystem to deal with additional outside stress. There is a relationship between the size of an area and the number of species that live in it. Forest fragmentation decreases forest size shifting species habitats closer to other species habitats and packing more diversity into a smaller area.

\section{Experimental and Analytical Problems}

A major shortcoming of TRFLP analysis is that only the terminal fragments are being read meaning two different sequences that share a terminal restriction site will produce one peak on the electropherogram. To decrease this drawback, several restriction enzymes plus labeling both primers with a different fluorescent dye can be done. In addition to the problem with TRFLP underestimating the total number of phylotypes, I also encountered the following experimental problems: First, I followed the Fierer and Jacksons (2006) protocol but I had poor amplification with the UltraClean Soil DNA Isolation kit (MoBio Laboratories). Dr. Rodrigue Spinette (URI) is experienced with the PowerSoil DNA Isolation kit (MoBio Laboratories), and suggested I bring my soil samples to his lab and try his modified protocol. We concluded that there was something in the soil that was inhibiting the DNA extraction/PCR reaction, but the PowerSoil DNA Isolation kit had additional steps (heating, cooling and cell lysis), and I finally acquired good amplification with this kit. Second, I ran into PCR problems (poor amplification or no 
amplification). Dr. Sarah Spinette (RIC) suggested I try different aliquots and different PCR conditions. I was adding too much DNA (100ng/ $\mu \mathrm{L})$ so instead I added $2 \mu \mathrm{L}$ of DNA (5 - 40ng) to the PCR reaction, and measured and concentrated the DNA after this step. The choice to use one restriction enzyme may be why the diversity of the soil communities was lower that expected. It was surprising that the same sample when aliquoted to two separate restriction digests only resulted in one good data set for a number of soil samples, but perhaps those samples were made up of communities with more phylotypes with the restriction site that RsaI targeted compared to HhaI.

The means of the environmental variables (soil $\mathrm{pH}$, soil temperature, and soil moisture) were calculated from four replicated data points per distance, which is a small sample size that increased the chance of a Type II error (failing to reject a false null hypothesis). TRFLP data analysis involves many steps that are time-consuming and error-prone. I attempted TRFLP three times with fresh soil samples each time. The DNA preparation work (DNA extraction, PCR, restriction digest, purification steps, running gels and TRFLP) was time-consuming but if I had had more time, I would have attempted TRFLP again until I achieved good amplification for all my samples. But due to the laborious nature of the DNA lab work, I had to work with a small sample size, reducing the statistical power of my analysis.

Although the differences in the environmental variables and in phylotype richness among sampling distances were not significant, the statistically significant difference in species diversity at the gap-forest edge is noteworthy. Even with the small sample size limitation, the data I collected are still useful to help design a larger, more robust study on gap edge effect on soil bacteria. I used Power Analysis (Samuels et al., 2012) to determine the sample size (n) needed to find a statistically significant difference (table 6). The sample size needed for soil temperature $\mathrm{n}$ 
$=140(\alpha=0.10$; power $=.50)$, at each distance, is high because soil temperature was measured in early spring (March) when there is little difference in temperature between forest and gap. In the summer, the gap gets warmer, and in the winter, the gap gets colder; therefore soil temperatures should be measured in the summer or the winter (or both), when temperature differences between gap and forest are at their greatest. Minimum sample size needed for a statistically significant difference for both soil $\mathrm{pH}$ and soil temperature was $\mathrm{n}=40(\alpha=0.05$; power $=.80)$ at each distance.

Possible future studies could identify what bacterial species (corresponding to phylotypes) are where along the gap-to-forest ecotone. This would be helpful because if we know what phylotypes of bacteria are present in the soil we can then research the functional group (nitrogenfixing bacteria (Rhizobia), nitrifying bacteria, denitrifying bacteria, Actinomycetes) a given phylotype belongs to and learn more about the structure and function of terrestrial ecosystems. Identification at the phylotype level could be done by searching a Basic Local Alignment Search Tool (BLAST) database of the 16s rRNA segments, or one could compare the sequences to a clone library (cDNA). Another option would be to match the terminal restriction fragments in the sample to patterns of $16 \mathrm{~S}$ rDNA fragments in a custom database of reference patterns. Another possible question this study could ask is, will bacterial diversity fully recover from forest fragmentation? This will depend on whether the phylotypes lost are $100 \%$ extinct or whether they are present in the soil at such low numbers that they are undetectable.

If I were to do this research over, I would still use the PowerSoil Isolation kit because only DNA is binding to the silica membrane, and I know RNA is not biding because the molecular weight of RNA is lower and passes through the membrane. I would test to see if the bacteria after the isolation step were viable or nonviable. To do this, I would do a plate count technique, which 
consists of serial dilutions and then growing the bacteria on a nutrient medium. I would use the same primers because they are designed to target the $16 \mathrm{~S}$ rRNA gene but I would tag both of them with different fluorescent labels. I would do some extra cleaning steps to the DNA before the restriction digest to remove any excess salts, inhibitors, or containments. Lastly, I would change my method of measuring diversity since the $\mathrm{Y}$-axis on the electropherograms (relative florescent units) is not a direct measurement of the actual number of individuals that make up that peak or phylotype. I would standardize raw peak height to balance the differences in the amount of DNA between samples by dividing the peak height by the sum of all peak heights of each sample.

In conclusion, an ecotone is a transition zone between two ecosystems that is influenced by its neighboring ecosystems, sometimes allowing greater biodiversity. The results of this study show that the creation of a gap influences the surrounding soil ecosystems, especially at the edge between the gap and forest. While the soil temperature, soil $\mathrm{pH}$ and soil gravimetric water moisture data were not significantly different along a gap-to-forest gradient; the gap was at the high or low range for all these environmental variables. This study showed soil phylotype diversity and richness was highest at the edge supporting my hypothesis and suggesting that more habitat niches are available to support greater species diversity at the edge. Species compete for resources within a community but an edge is a mixed microhabitat of gap and forest with more resources available that can support more species at the ecotone. Gap-edge studies are important for learning about biodiversity, adaptations, and ecological processes which can aid in better understanding of population dynamics and species interactions to a changing climate, and understanding ecotone function, structure, and relationships can improve conservation strategies in fragmented forests. 


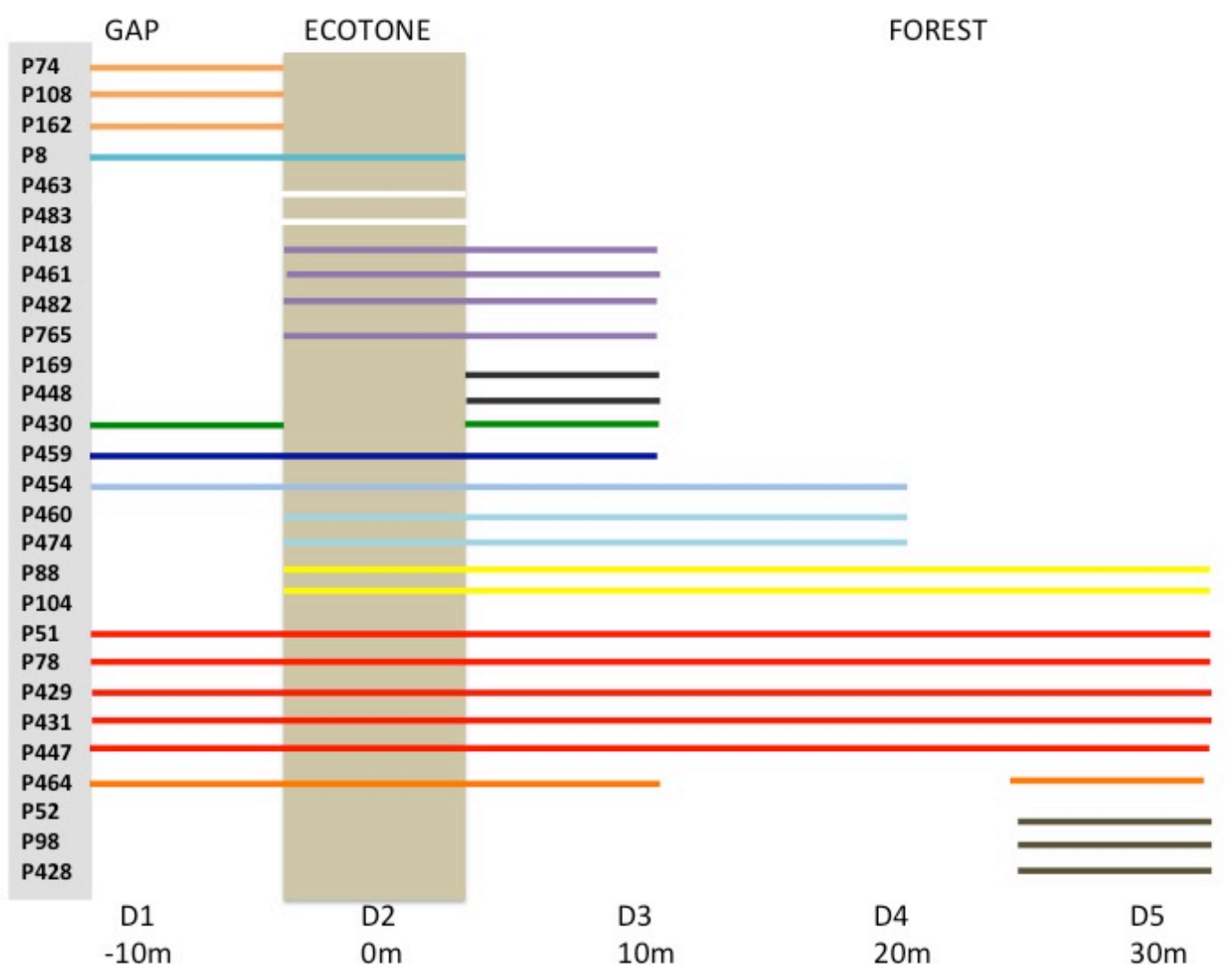

Figure 15 Adapted from Ricklefs (2001)

Table 6 SamplePower Statistics

\begin{tabular}{|c|c|c|c|c|c|c|c|c|c|c|c|c|}
\hline & $\begin{array}{c}\text { mean } \\
\text { gap }\end{array}$ & $\begin{array}{l}\text { mean } \\
\text { forest }\end{array}$ & $\begin{array}{l}\text { SE } \\
\text { gap }\end{array}$ & $\begin{array}{c}\text { SE } \\
\text { forest }\end{array}$ & $\begin{array}{l}\text { Std. Dev. } \\
\text { gap }\end{array}$ & $\begin{array}{c}\text { Std. Dev. } \\
\text { Forest }\end{array}$ & $\begin{array}{l}\text { Avg. } \\
\text { SD }(\sigma)\end{array}$ & $\begin{array}{l}\text { effect } \\
\text { size }\end{array}$ & * & $\begin{array}{c}* \\
\text { Power }\end{array}$ & $\begin{array}{c}\mathrm{n} \\
\text { gap }\end{array}$ & $\begin{array}{r}r \\
\text { for }\end{array}$ \\
\hline $\mathrm{pH}$ & 5.88 & 5.65 & 0.149 & 0.12216 & 0.29861 & 0.42319 & 0.361 & 0.65 & $\begin{array}{c}0.0 \\
5\end{array}$ & 0.80 & 40 & 4 \\
\hline temp & 10.95 & 11.39 & 1.198 & 0.615181 & 2.38956 & 2.13321 & 2.26 & 0.2 & $\begin{array}{l}0.1 \\
0.0\end{array}$ & 0.50 & 140 & $1<$ \\
\hline moisture & 46.5 & 38.1 & 7.376 & 3.17533 & 14.75353 & 10.99966 & 12.87 & 0.65 & 5 & 0.80 & 40 & 4 \\
\hline
\end{tabular}

* Samuels et al. 2012 Statistics for Life Sciences Prentice Hall 
Aber, J.D., and Foster D.R.. (2004) Forests in Time: The Environmental Consequences of 1000 Years of Change in New England. Yale University Press, New Haven, CT. pages 3-18

Abrams, M.D. (2003) Where Has All the White Oak Gone? BioScience, 53 (10):927-939.

Adams, E.E. (2012) World forest area still on the decline. Earth Policy Institute http://earthpolicyinstitute.libsyn.com/world-forest-area-still-on-the-decline.

Alerich, C.L. (2000) Forest Statistics for Rhode Island: 1985 and 1998. USDA Forest Service Resource Bulletin NE-149:1-3.

Baker, J., French, K. \& Whelan, R.J. (2002) The edge effect and ecotonal species: bird communities across a natural edge in southeastern Australia. Ecology, 83:3048-3059.

Bauhus, J. (1996) C and N mineralization in an acid forest soil along a gap-stand gradient. Soil Biology and Biochemistry, 28(7):923-932.

Broadbenta, E.N., Asner, G.P., Keller, M., Knapp, D.E., Oliceria, P.J., \& Silva, J.N. (2008). Forest fragmentation and edge effects from deforestation and selective logging in the Brazilian Amazon. Biological Conservation, 141(7):1745-1757.

Butler, B.J., Barnett, C.H., Dolan, P., Dupree, T.A., Emery, M., Lister, A., Lister, T.W., Ricard, P., Sparks, C., Wharton, E.H. \& Widmann, R.H. (2002) The forests of Rhode Island. NEINF-155-02. Newtown Square: U.S. Department of Agriculture, Forest Service, Northeastern Research Station. 28 p.

Butler, B.J., Barnett, C.J., Crocker, S.J., Domke, G.M., Gormanson, D., Hill, W.N., Kurtz, C.M., Lister, T., Martin, C., Miles, P.D., Morin, R., Moser, W.K., Nelson, M.D., O’Connell, B., Payton, B., Perry, C.H., Piva, R.J., Riemann, R. \& Woodall, C.W. (2011) The forests of Southern New England, 2007: a report on the forest resources of Connecticut, Massachusetts, and Rhode Island. Resour. Bull. NRS-55. Newtown Square, PA: U.S. Department of Agriculture, Forest Service, And Northern Research Station. 48 p.

Castro, H.F., Classen, A.T., Richard, A.E., Norby, J. \& Schadt, C.W. (2010) Soil microbial community responses to multiple experimental climate change drivers. Appl. Environ. Microbiol., 76(4):999-1007.

Clark, A.J. \& Covey, R.K. (2012) Tree species richness and the logging of natural forests: A meta-analysis. Forest Ecology and Management, 276: 146-153.

Cochrane, M.A. (2002) Synergistic Interactions between habitat fragmentation and fire in evergreen tropical forests. Conservation Biology, 15(6):1515-1521. 
Curiel, J.Y. (2013) Strong functional stability of soil microbial communities under semiarid Mediterranean conditions and subjected to long-term shifts in baseline precipitation. Soil Biology \& Biochemistry, 69:223-233.

Dangerfield, J.M., Pik, J.A., Britton D., Holmes, A., Gillings, M., Oliver, I., Briscoe, D. \& Beattie, J.A. (2003) Patterns of invertebrate biodiversity across a natural edge Austral Ecology, 28:227-236.

DeGouvenain, C.R. \& Silander, A.J. (2003) Do Tropical Storm Regimes Influence the Structure of Tropical Lowland Rain Forests Biotropica, 35(2): 166-180.

FAO. 2009. State of the World's Forests - 2009. Food and Agricultural Organization of the United Nations.

Fergnani, P.F., Nilda, P., Sackmann, P. \& Ruggiero, A (2013) The spatial variation in ant species composition and functional groups across the Subantartic-Patagonian transition zone Insect Conserv, 17:295-305.

Fierer, N, \& Jackson, RB. (2006) The diversity and biogeography of soil bacterial communities. Proceedings of the National Academy of Sciences USA, 103:626-631,

Garbeva, P., van Veen J.A. \& van Elsas, J.D. (2004) Microbial diversity in soil: selection of microbial populations by plant and soil type and implications for soil suppressiveness. Ann. Rev. Phytopathol., 42:243-270.

Grüntzig, V. (2002) "Improved Protocol for T-RFLP by Capillary Electrophoresis." The Ribosomal Database Project (RDP). (http://rdp8.cme.msu.edu/html/t-rflp_jul02.html).

Harper, K.A., Macdonald, E., Burton, P.J., Chens, J., \& Brosofske, K.D. (2005) Edge influence on forest structure and composition in fragmented landscapes. Conservation Biology, 19(3):768-782.

Horner-Devine, C.M., Carney, K.K. \& Bohannan, B.J. (2004) An ecological perspective on microbel biodiversity. Proc Biol Sci, 271:113-122.

Hooper, D.U. (2005) Effects of biodiversity on ecosystem functioning: a consensus of current knowledge. Ecol. Monogr., 75:3-35. (doi:10.1890/04-0922).

Hufkens, K., Scheunders, P. \& Ceulemans, R. (2008) Ecotones in vegetation ecology: methodologies and definitions. The Ecological Society of Japan.

Ikeda, S., Ytow, N., Ezura, H., Minamisawa, K. \& Fujimura, T.F. (2004) Soil microbial community analysis in the environmental risk assessment of transgenic plants. Plant Biotechnology, 23:137-151. 
Janda, J.M. \& Abbott, S.L., (2010) The genus Aeromonas: taxonomy, pathogenicity, and infection. American Society for Microbiology, 23, 35-73.

Kamayev, I.O. (2012) Spider (Aranei) assemblages in bog-forest ecotone of the northern taiga subzone (Eastern Fennoscandia). Entomological Review, 92(4):471-485.

Kardol, P. \& Wardle, D.A. (2010) How understanding aboveground-belowground linkages can assist restoration ecology. Trends Ecol. Evol..11:670-679.

Kirk, J.L., Beaudette, L.A., Hart, M., Moutoglis, P., Klironomos, J.N. \& Lee, H., (2004) Methods of studying soil microbial diversity. Journal of Microbiological Methods, 58:169188.

Kunin, W.E. (1998) Biodiversity at the edge: a test of the importance of spatial mass effects in the Rothamsted Park Grass experiments. Proc. Natl Acad. Sci. U.S.A., 95:207-212.

Leslie T.W., Biddinger, D.J., Rohr, J.R., Hulting, A.G., Mortensen, D.A. \& Fleischer, S. J. (2014) Examining Shifts in Carabidae Assemblages Across a Forest-Agriculture Environmental Entomology, 43(1):18-28..

Mascarúa-López, L.E., Harper, K.A. \& Drapeau, P. (2006) Edge influence on forest structure in large forest remnants, cutblock separators and riparian buffers in managed black spruce forests. Ecoscience. 13:226-233.

Lorimer, C.J. \& White, A.S. (2003) Scale and frequency of natural disturbances in the northeastern US: implications for early successional forest habitats and regional age distributions. Forest Ecology and Management, 185:41-64.

McArthur, V.J., Kovacic, D.A. \& Smith, M.H. (1988) Genetic diversity in natural populations of a soil bacterium across a landscape gradient. Proceedings of the National Academy of Sciences U.S.A., 85:9621-9624.

McDonald, R.I. \& Urban, D.L. (2004) Forest edges and tree growth rates in the North Carolina Piedmont. Ecology, 85(8):2258-2266.

McLoughlin, W.G. (1976) Rhode Island: A History (States and the Nation).

Mourelle, C., Kellman, M. \& Kwon, L. (2001) Light occlusion at forest edges: an analysis of tree architectural characteristics. Forest Ecology and Management, 154(1-2):179-192.

Miiller, A.K., Westergaard, K, Christensen, S. \& Sorensen, S.J. (2002) The diversity and function of soil microbial communities exposed to different disturbances. Microbial Ecology 44:49-58.

Nannipieri, P. Ascher, J. Ceccherini, M.T., Landi, L. Pietramellara, G. \& Renella, G. (2003) Microbial diversity and soil functions. European Journal of Soil Science, 54(4):655-670. 
Neher, D. (1999) Soil community composition and ecosystem processes Comparing agricultural ecosystems with natural ecosystems. Agroforestry Systems. 45:159-185.

Odum, E.P. (1971) Fundamentals of ecology, $3^{\text {rd }}$ edition. Philadelphia, PA: W. B. Saunders Company. 574 pp.

Osborn, A.M., Moore, E.R.B. \& Timmis, K.N. (2000) An evaluation of terminal restriction fragment length polymorphism (T-RFLP) analysis for the study of microbial community structure and dynamics. Environ. Microbiol. 2:39-50.

Ricklefs, R.E (2001) The Economy of Nature. $5^{\text {th }}$ ed. Freeman \& Co. New York. 405 pp.

Ries, L., Fletcher, R.J., Battin, J. \& Sisk, T.D. (2004) Ecological responses to habitat edges: Mechanisms, models, and variability explained. Annual Review of Ecology, Evolution and Systematics. 35:491-522.

Salvador-Van Eysenrode, D., Kockelbergh, F., Bogaert, J., Impens, I. \& Van Hecke, P. (2002). Canopy gap edge determination and the importance of gap edges for plant diversity. Web Ecology, 3:1-5.

Samuels, M.L., Witmer, J.A \& Schaffner, A.A (2012) Statistics for the life sciences, $4^{\text {th }}$ edition. Prentice Hall, Boston. pp. 574-575

Scharenbroch, B.C. \& Bockheim, J.G. (2007). Impacts of forest gaps on soil properties and processes in old growth northern hardwood-hemlock forests. Plant Soil, 294:219-233.

Schloss, P.D. \& Westcott, S.L. (2011) Assessing and improving methods used in operational taxonomic unit-based approaches for 16S rRNA gene sequence analysis. Applied and Environmental Microbiology, .

Schutte, U.M., Abdo, E.Z., Bent, S.J., Shyu, C., Williams, C.J., Pierson, J. D. \& Forney, L.J. (2008) Advances in the use of terminal restriction fragment length polymorphism (T-RFLP) analysis of $16 \mathrm{~S}$ rRNA genes to characterize microbial communities. Appl. Microbiol. Biotechnol., 80:365-380.

Sokal, R.R. \& Crovello, T.J., (1970) The biological species concept: A critical evaluation. The American Naturalist. 104(936):127-153.

ter Braak, C.J.F. (1986) Canonical correspondence analysis: a new eigenvector technique for multivariate direct gradient analysis. Ecology, 67:1167-1179.

Thies, J.E. (2007) Soil microbial community analysis using terminal restriction fragment length polymorphisms. Soil Science Society American Journal, 71(2):579-591. 
Thomas C., Gattinger A., Jacob M., Thomas F.M. \& Gleixner G. (2010) Direct and indirect effects of tree diversity soil microbial diversity in temperature deciduous forest. Soil Biol. Biochem., 42:1558-1565.

Thomas, P. \& Packham, J (2007) Ecology of Woodlands and Forests: Description, Dynamics and Diversity

Torsvik, V. \& Ovreas, L. (2002). Microbial diversity and function in soil: from genes to ecosystems. Current Opinion in Microbiology, 5:240-245.

van der Putten, W.H., Bardgett, R. D., Meyer, K.M., Bradford, M.A., Christensen, S., Eppinga, M.B., Fukami, T., Hemerik, L., Molofsky, J. \& Scherber, C. (2009) Empirical and theoretical challenges in aboveground-belowground ecology. Oecologia, 161(1):1-14.

Van Horn, D.J., Van Horn, M.L., Barrett, J.E., Gooseff, M.N. \& Altrichter, A.E. (2013) Factors controlling soil microbial biomass and bacterial diversity and community composition in a cold desert ecosystem: Role of geographic scale. PLoS ONE 8(6): e66103. doi: 10.1371/journal.pone.0066103.

Wade, T.G., Riitters, K.H., Wickham, J.D. \& Jones, K.B. (2003) Distribution and causes of global forest fragmentation. Conservation Ecology, 7(2):1-16.

Wall, D.H. \& Moore, J.C. (1999) Interactions underground, soil biodiversity, mutualsim, and ecosystem functioning. Bioscience, 49(2):109-117.

Wardle, D.A., Bardgett, R.D., Klironomos, J.N., Setälä, H., van der Putten, W.H. \& Wall, D.H. (2004) Ecological linkages between aboveground and belowground biota. Science, 304(5677):1629-1633.

Watkins, R.Z., Pickens, C.J. \& Brosofske, K.D. (2003) Effects of forest roads on understory plants in a managed hardwood landscape. Conservation Biology 17: 411-419. -doi: 10.1046/j.1523-1739.2003.01285.x.

Widmann, R.H., Wharton, E.H., Alerich, C.L., Barnett, C.J. \& Lister, A.J. (2004) The Forests of Connecticut. United States Department of Agriculture. NE-160, p. 35pp

Woese. C.R. (2000) Interpreting the universal phylogenetic tree. Proc Natl Acad Sci U.S.A., 97(15):8392-8396. 